\title{
Antitumor effects of arsenic disulfide on the viability, migratory ability, apoptosis and autophagy of breast cancer cells
}

\author{
YUXUE ZHAO $^{1,2}$, KENJI ONDA ${ }^{1}$, KENTARO SUGIYAMA ${ }^{1}$, BO YUAN ${ }^{3}$, SACHIKO TANAKA $^{1}$, \\ NORIO TAKAGI ${ }^{3}$ and TOSHIHIKO HIRANO ${ }^{1}$ \\ ${ }^{1}$ Department of Clinical Pharmacology, School of Pharmacy, Tokyo University of Pharmacy and Life Sciences, \\ Hachioji, Tokyo 192-0392, Japan; 2 Institute of Acupuncture and Moxibustion, \\ China Academy of Chinese Medical Sciences, Beijing 100700, P.R. China; \\ ${ }^{3}$ Department of Applied Biochemistry, School of Pharmacy, \\ Tokyo University of Pharmacy and Life Sciences, \\ Hachioji, Tokyo 192-0392, Japan
}

Received March 23, 2018; Accepted September 4, 2018

DOI: $10.3892 / o r .2018 .6780$

\begin{abstract}
In the present study, the antitumor effects of arsenic disulfide $\left(\mathrm{As}_{2} \mathrm{~S}_{2}\right)$ on the proliferative, survival and migratory ability of human breast cancer MCF-7 and MDA-MB-231 cells were investigated, and its potential underlying molecular mechanisms with an emphasis on cell cycle arrest, apoptosis induction, autophagy induction and reactive oxygen species (ROS) generation were determined. The results indicated that $\mathrm{As}_{2} \mathrm{~S}_{2}$ significantly inhibited the viability, survival and migration of breast cancer cells in a dose-dependent manner. In addition, it was identified that $\mathrm{As}_{2} \mathrm{~S}_{2}$ induced cell cycle arrest primarily at $\mathrm{G}_{2} / \mathrm{M}$ phase in the two breast cancer cell lines by regulating the expression of associated proteins, including cyclin B1 and cell division cycle protein 2 . In addition to cell cycle arrest, $\mathrm{As}_{2} \mathrm{~S}_{2}$ also triggered the induction of apoptosis in cells by activating the expression of pro-apoptotic proteins, including caspase-7 and -8, as well as increasing the B-cell lymphoma 2 (Bcl-2)-associated $\mathrm{X}$ protein/Bcl-2 ratio, while
\end{abstract}

Correspondence to: Professor Toshihiko Hirano, Department of Clinical Pharmacology, School of Pharmacy, Tokyo University of Pharmacy and Life Sciences, 1432-1 Horinouchi, Hachioji, Tokyo 192-0392, Japan

E-mail: hiranot@toyaku.ac.jp

Abbreviations: ATO, arsenic trioxide; APL, acute promyelocytic leukemia; PCD, programmed cell death; CCK-8, Cell Counting Kit-8; PI, propidium iodide; CQ, chloroquine diphosphate; MMP-9, matrix metalloproteinase-9; Bcl-2, B-cell lymphoma 2; Bcl-xl, B-cell lymphoma extra-large; Bax, Bcl-2-associated X protein; Cdc2, cell division cycle protein 2; LC3, microtubule-associated protein 1A/1B-light chain 3; DCF-DA, 2',7'-dichlorofluorescin diacetate; ROS, reactive oxygen species

Key words: arsenic disulfide, breast cancer cells, apoptosis, cell cycle, autophagy, reactive oxygen species decreasing the protein expression of anti-apoptotic B-cell lymphoma extra-large. In addition, $\mathrm{As}_{2} \mathrm{~S}_{2}$ stimulated the accumulation of microtubule-associated protein 1A/1B-light chain 3 (LC3)-II and increased the LC3-II/LC3-I ratio, indicating the occurrence of autophagy. $\mathrm{As}_{2} \mathrm{~S}_{2}$ treatment also inhibited the protein expression of matrix metalloproteinase-9 (MMP-9), but increased the intracellular accumulation of ROS in the two breast cancer cell lines, which may assist in alleviating metastasis and attenuating the progression of breast cancer. Taken together, the results of the present study suggest that $\mathrm{As}_{2} \mathrm{~S}_{2}$ inhibits the progression of human breast cancer cells through the regulation of cell cycle arrest, intrinsic and extrinsic apoptosis, autophagy, MMP-9 signaling and ROS generation.

\section{Introduction}

Arsenic disulfide $\left(\mathrm{As}_{2} \mathrm{~S}_{2}\right)$ is an orange-red crystalline mineral and the principal effective component of realgar, and has been used extensively to treat various diseases in ancient China and Europe (1). In recent decades, a series of studies have revealed the marked therapeutic potential of $\mathrm{As}_{2} \mathrm{~S}_{2}$ in hematopoietic tumors, particularly acute promyelocytic leukemia (APL) (2-4). In addition, recent evidence has revealed the potent anticancer effect of $\mathrm{As}_{2} \mathrm{~S}_{2}$ against various human solid cancer cell lines, but with markedly decreased toxicity in normal somatic cells (5-7). Previous studies have demonstrated that $\mathrm{As}_{2} \mathrm{~S}_{2}$ exerts potent anticancer effects in human hepatocellular carcinoma cells, cervical cancer cells, endometrial cancer cells, ovarian cancer cells, malignant melanoma cells, pancreatic carcinoma cells and gastric cancer cells, whereas human normal fibroblast cell lines and other human normal cells, including a lung fibroblast cell line (MRC-5), dermal fibroblast cells (HF and Hs-68), embryonic liver cells (L02) and normal breast epithelial cells (184B5), were much less markedly affected by $\mathrm{As}_{2} \mathrm{~S}_{2}$ treatment (8-12). However, relatively few studies have investigated the potential antitumor activity of $\mathrm{As}_{2} \mathrm{~S}_{2}$ in human breast carcinoma and its underlying molecular mechanisms (12-14). 
Breast cancer is one of the most common malignancies among women $(15,16)$. Although conventional therapies, such as chemotherapy and radiotherapy, have improved the outcomes for patients with breast cancer, drug resistance and high rates of recurrence still hamper their efficacies in clinical application (17). Arsenic trioxide (ATO) has been approved by the US Food and Drug Administration in 2000 as an agent for the treatment of APL (18) and reportedly has promising therapeutic potential against breast cancer (19). $\mathrm{As}_{2} \mathrm{~S}_{2}$ has a number of benefits over ATO, including a relatively low toxicity and safety in oral administration, while exerting a similar antitumor effect $(20,21)$. Exploring the antitumor effects of $\mathrm{As}_{2} \mathrm{~S}_{2}$ against breast carcinoma might thus shed new light on the therapeutic potential of this arsenic compound for the treatment of breast cancer.

Programmed cell death (PCD), which refers to any form of cell death mediated by an intracellular death program, serves a fundamental function in biological homeostasis $(22,23)$. Dysregulation of this self-destructive process leads to various human diseases, including breast cancer. Apoptosis (type I cell death) and autophagy (type II cell death) are the two primary forms of PCD defined on the basis of morphological criteria $(23,24)$. Apoptosis, the primary and most well-researched mode of PCD, has been regarded as the principal pathway of PCD (25). Apoptosis induction serves an essential function in anticancer chemotherapies against various types of cancer (26). Autophagy is a highly regulated catabolic process that enables cells to clean up and degrade their own cytoplasmic components $(24,27)$. Autophagy induction is attributed to various stresses that ultimately lead to apoptosis, and organelle dysfunction, metabolic stress, chemotherapies, pathogen infection and starvation are known to induce autophagy (25). There is a complex connection between apoptosis and autophagy; indeed, apoptosis may begin with autophagy, and autophagy may end with apoptosis. It has been suggested that targeting these two self-destructive processes may be a particularly useful chemotherapeutic strategy in the treatment of cancer (28), including breast cancer (29). Accumulating evidence has indicated that apoptosis and autophagy can be induced by $\mathrm{As}_{2} \mathrm{~S}_{2}$ treatment in hematopoietic as well as solid cancer cell lines $(8,30,31)$. Our previous studies revealed the inhibitory effect of $\mathrm{As}_{2} \mathrm{~S}_{2}$ on breast cancer cells, mediated by the induction of apoptosis $(12,13)$. However, the molecular mechanism underlying the involvement of $\mathrm{As}_{2} \mathrm{~S}_{2}$ in apoptosis and autophagy in breast cancer cells remains unclear, warranting further investigation.

Reactive oxygen species (ROS), as a common indicator of oxidative stress, consist of superoxide, hydrogen peroxide and the hydroxyl free radical $(32,33)$. ROS production by xenobiotics selectively kills cancer cells with negligible effects on normal cells (34). Intriguingly, arsenic compounds promote the generation of ROS, and this increased ROS accumulation mediates the genotoxicity of arsenic in cancer cells, thereby facilitating the induction of apoptosis (35-37). ROS therefore serve a pivotal function in cancer cell death caused by arsenic compounds, making them a tempting target for an $\mathrm{As}_{2} \mathrm{~S}_{2}$-based strategy of cytotoxic intervention in breast carcinoma.

The aim of the present study was to investigate the anticancer effects of $\mathrm{As}_{2} \mathrm{~S}_{2}$ in human breast cancer cells in vitro and the potential underlying molecular mechanisms involved, particularly with respect to the induction of PCD and the generation of ROS.

\section{Materials and methods}

Reagents. Cell Counting Kit-8 (CCK-8) was purchased from Dojindo Molecular Technologies, Inc. (Kumamoto, Japan). Calcein-acetoxymethyl ester (AM) and Hoechst 33342 were purchased from Molecular Probes; Thermo Fisher Scientific, Inc. (Waltham, MA, USA). A Fluorescein Isothiocyanate (FITC)-Phycoerythrin Annexin V Apoptosis Detection kit was obtained from BD Biosciences (San Jose, CA, USA). $\mathrm{As}_{2} \mathrm{~S}_{2}$, propidium iodide (PI), RNase A solution and 2',7'-dichlorofluorescin diacetate (DCF-DA) were purchased from Sigma; Merck KGaA (Darmstadt, Germany). Chloroquine diphosphate (CQ) was purchased from Wako Pure Chemical Industries, Ltd. (Osaka, Japan). An Enhanced Chemiluminescence (ECL) Western Blotting Analysis system and ECL Prime Western Blotting Detection reagent were purchased from GE Healthcare Life Sciences (Little Chalfont, UK). Rabbit anti-human matrix metalloproteinase-9 (MMP-9), rabbit anti-human B-cell lymphoma 2 (Bcl-2), rabbit anti-human B-cell lymphoma extra-large (Bcl-xl), rabbit anti-human caspase-7, mouse anti-human caspase-8, rabbit anti-human microtubule-associated protein 1A/1B-light chain 3 (LC3A/B), mouse anti-human cyclin B1 and rabbit anti-human cell division cycle protein 2 (Cdc2) were obtained from Cell Signaling Technology, Inc. (Danvers, MA, USA). Mouse anti-human Bcl-2-associated X protein (Bax) was purchased from Sigma; Merck KGaA.

Cell lines and cell culture. The human breast cancer MCF-7 and MDA-MB-231 cell lines were purchased from the American Type Culture Collection (Manassas, VA, USA). Cells were cultured in $\alpha$-minimal essential medium (Gibco; Thermo Fisher Scientific, Inc.) supplemented with $1 \%$ penicillin/streptomycin and fetal bovine serum (10\% for MCF-7 and 15\% for MDA-MB-231; Sigma; Merck KGaA). The cells were cultured and maintained as attached cells at $37^{\circ} \mathrm{C}$ in a humidified atmosphere containing $5 \% \mathrm{CO}_{2}$.

Cell culture assays and drug treatment. MCF-7 and MDAMB-231 cells were seeded at 10,000 and 15,000 cells/well, respectively, in $500 \mu \mathrm{l}$ cell culture medium on 48 -well plates (Iwaki microplates; Iwaki Co., Ltd., Tokyo, Japan), followed by overnight incubation at $37^{\circ} \mathrm{C} . \mathrm{As}_{2} \mathrm{~S}_{2}$ was subsequently added to the corresponding wells to adjust the final drug concentrations to between 0 and $16 \mu \mathrm{M}$. MCF-7 and MDA-MB-231 cells were allowed to grow for $48 \mathrm{~h}$ in the presence of different concentrations of $\mathrm{As}_{2} \mathrm{~S}_{2}$, followed by a cytotoxicity assay.

Cytotoxicity assay. Cell cytotoxicity was analyzed using a CCK-8 assay. For each cell line, $\sim 1 \times 10^{4}$ cells/well were seeded into 48-well plates. $\mathrm{As}_{2} \mathrm{~S}_{2}$ was subsequently added to the corresponding wells to adjust the final drug concentrations to between 0 and $16 \mu \mathrm{M}$. The plates were then incubated at $37^{\circ} \mathrm{C}$ in a humidified atmosphere containing $5 \% \mathrm{CO}_{2}$ for $48 \mathrm{~h}$. Following incubation, $25 \mu \mathrm{l}$ CCK- 8 reagent was added to each well, followed by further incubation at $37^{\circ} \mathrm{C}$ for $3 \mathrm{~h}$. The optical density (OD) value of each well was determined using 
a microplate reader (Corona MT P-32; Corona Co., Ibaraki, Japan) at $570 \mathrm{~nm}$. The cell viability rate was calculated according to the following equation: Cell viability rate $=(\mathrm{OD}$ sample value - OD blank value)/(OD control value - OD blank value) $\mathrm{x} 100 \%$.

Morphological analysis and cell viability assay. MCF-7 and MDA-MB-231 cells were seeded onto a 96-well plate at $5 \times 10^{3}$ cells/well in $100 \mu \mathrm{l}$ culture medium, followed by exposure to different concentrations of $\mathrm{As}_{2} \mathrm{~S}_{2}(0,4,8$ and $16 \mu \mathrm{M}$ ) for $48 \mathrm{~h}$. The cells were then stained for $15 \mathrm{~min}$ in the dark at $37^{\circ} \mathrm{C}$ with the specific live probe calcein-AM, prior to capturing images and analysis using an Operetta CLS fluorescence microplate reader (PerkinElmer, Inc., Waltham, MA, USA) and the Harmony software program (version 4.5; PerkinElmer, Inc.).

Wound healing assay. Migration was determined using a wound scratching assay. Cells were seeded at $4 \times 10^{5}$ cells/well in 6-well plates (Iwaki microplates) and cultured for $24 \mathrm{~h}$ to form a confluent cell monolayer. A wound was then scratched onto the cells using a sterile micropipette tip. The cells were washed with PBS and treated with various concentrations of $\mathrm{As}_{2} \mathrm{~S}_{2}(0,8$ and $16 \mu \mathrm{M})$, followed by further incubation for $48 \mathrm{~h}$. Images of each scratch at the same location were captured at 0 and $48 \mathrm{~h}$ using an IX70 ${ }^{\circledR}$ inverted microscope (magnification, x100) (Olympus Corporation, Tokyo, Japan). Cell migration was quantified by measuring the wound opening area using the ImageJ program (version $1.50 \mathrm{i}$, National Institutes of Health, Bethesda, MD, USA).

Cell cycle analyses. MCF-7 and MDA-MB-231 cells were seeded at $4 \times 10^{5}$ cells/well in 6 -well plates (Iwaki microplates), followed by overnight incubation. Cells were treated with 0 , 4, 8 and $16 \mu \mathrm{M} \mathrm{As} \mathrm{S}_{2}$, followed by a further $48 \mathrm{~h}$ of incubation at $37^{\circ} \mathrm{C}$. Cells were harvested and washed with PBS twice. Cells were fixed in $70 \%$ ethanol overnight at $-20^{\circ} \mathrm{C}$ and stained with PI and RNase A solution $(5 \mu \mathrm{g} / \mathrm{ml}$ PI and $0.5 \mu \mathrm{g} / \mu 1 \mathrm{RNase} \mathrm{A})$. The DNA content was determined by flow cytometry (BD Biosciences), and data were analyzed using the cell cycle analysis software program ModFit LT (version 3.0; Verity Software House, Inc., Topsham, ME, USA).

Morphological characteristics of apoptosis. Hoechst 33342 staining was performed to observe morphological characteristics of apoptotic cells. MCF-7 and MDA-MB-231 cells were seeded onto a 96 -well plate at $5 \times 10^{3}$ cells/well, followed by exposure to different concentrations of $\mathrm{As}_{2} \mathrm{~S}_{2}(0$, 4,8 and $16 \mu \mathrm{M}$ ) for $48 \mathrm{~h}$. The cells were then stained with Hoechst 33342 solution at $37^{\circ} \mathrm{C}$ for $15 \mathrm{~min}$ in the dark. The cells were observed and analyzed for morphological changes of the nucleus using a fluorescence microplate reader and the Harmony software program.

Assessment of apoptosis. MCF-7 and MDA-MB-231 cells were seeded at $2 \times 10^{5}$ cells/well in 6 -well plates $(2 \mathrm{ml} /$ well $)$ and treated with serial concentrations of $\mathrm{As}_{2} \mathrm{~S}_{2}(0,4,8$ and $16 \mu \mathrm{M})$, followed by additional incubation for $48 \mathrm{~h}$ at $37^{\circ} \mathrm{C}$. The apoptotic rates for the two cell lines were determined using an FITC-Annexin V Apoptosis Detection kit. The staining procedure was performed according to the manufacturer's protocol. In total, $\sim 1 \times 10^{4}$ cells were analyzed using a flow cytometer and BD FACSDiva software (version 6.0; BD Biosciences). The cells were subsequently assessed for the total number of apoptotic cells, including early-apoptotic (Annexin $\mathrm{V}^{+} / \mathrm{PI}^{-}$) and late-apoptotic (Annexin $\mathrm{V}^{+} / \mathrm{PI}^{+}$) cells.

Autophagy inhibition in breast cancer cells. To examine whether or not $\mathrm{As}_{2} \mathrm{~S}_{2}$-induced cell death was mediated through autophagy, the autophagy inhibitor CQ $(10 \mu \mathrm{M})$ was added to MCF-7 and MDA-MB-231 cells $1 \mathrm{~h}$ prior to the addition of $\mathrm{As}_{2} \mathrm{~S}_{2}$. Subsequently, $\mathrm{As}_{2} \mathrm{~S}_{2}$ was added at concentrations of $0,4,8$ and $16 \mu \mathrm{M}$. After $48 \mathrm{~h}$ of treatment, the CCK- 8 assay was performed as aforementioned.

Western blot analyses. The standard Western blot protocol was performed in order to evaluate the protein levels of Bcl-2, Bax, Bcl-xl, caspase-7, caspase-8, cyclin B1, Cdc2 and LC3A/B in MCF-7 and MDA-MB-231 cells. The total protein content was extracted from each cell line treated by $\mathrm{As}_{2} \mathrm{~S}_{2}$ at various final concentrations $(0,4,8$ and $16 \mu \mathrm{M})$ for $48 \mathrm{~h}$. In brief, cell lysates were separated by SDS-PAGE $(12.5 \%$ gel) and transferred onto a polyvinylidene difluoride transfer membrane (Immobilon-P; Merck KGaA). Membranes were blocked with $5 \%$ dried skimmed milk powder in Tris-buffered saline containing $0.2 \%$ Tween-20 (TBST) for $1 \mathrm{~h}$ at room temperature. The membranes were washed with TBST and incubated overnight at $4^{\circ} \mathrm{C}$ with $1: 1,000$ anti-rabbit MMP-9 specific antibody (cat. no. 3852; Cell Signaling Technology, Inc.), 1:1,000 anti-rabbit Bcl-2 specific antibody (cat. no. 4223; Cell Signaling Technology, Inc.), 1:1,000 anti-rabbit Bcl-xl specific antibody (cat. no. 2764; Cell Signaling Technology, Inc.), 1:500 anti-mouse Bax specific antibody (cat. no. B8429; Sigma; Merck KGaA), 1:1,000 anti-rabbit caspase-7 specific antibody (cat. no. 12827; Cell Signaling Technology, Inc.), 1:1,000 anti-mouse caspase- 8 specific antibody (cat. no. 9746; Cell Signaling Technology, Inc.), 1:1,000 anti-mouse cyclin B1 specific antibody (cat.no.4135; Cell Signaling Technology,Inc.), 1:1,000 anti-rabbit Cdc2 specific antibody (cat. no. 9112; Cell Signaling Technology, Inc.) and 1:1,000 anti-rabbit LC3A/B specific antibody (cat. no. 12741; Cell Signaling Technology, Inc.). Membranes were also probed with anti- $\beta$-actin antibody (cat. no. ab49900; Abcam, Cambridge, UK) at 1:4,000 dilution as the internal control. The membranes were incubated with the aforementioned primary antibodies at $4^{\circ} \mathrm{C}$ overnight and then incubated with 1:1,000 anti-mouse (cat. no. 7076; Cell Signaling Technology, Inc.) or 1:1,000 anti-rabbit (cat. no. 7074; Cell Signaling Technology, Inc.) specific polyclonal secondary antibodies for $1 \mathrm{~h}$ at room temperature, followed by washing three times with TBST. Signals were detected using an ECL Western Blot detection kit in a luminescent image analyzer (LAS-3000; Fujifilm Corporation, Tokyo, Japan).

Determination of ROS. MCF-7 and MDA-MB-231 cells were seeded at $4 \times 10^{5}$ cells/well in 6-well plates (Iwaki microplates), followed by overnight incubation at $37^{\circ} \mathrm{C}$. Cells were treated with different concentrations of $\mathrm{As}_{2} \mathrm{~S}_{2}(0,4,8$ and $16 \mu \mathrm{M})$, followed by an additional incubation for $48 \mathrm{~h}$. DCF-DA was then added to the two cell lines to a final concentration of $10 \mu \mathrm{M}$ and incubated at $37^{\circ} \mathrm{C}$ for $30 \mathrm{~min}$ in the dark. Subsequently, 

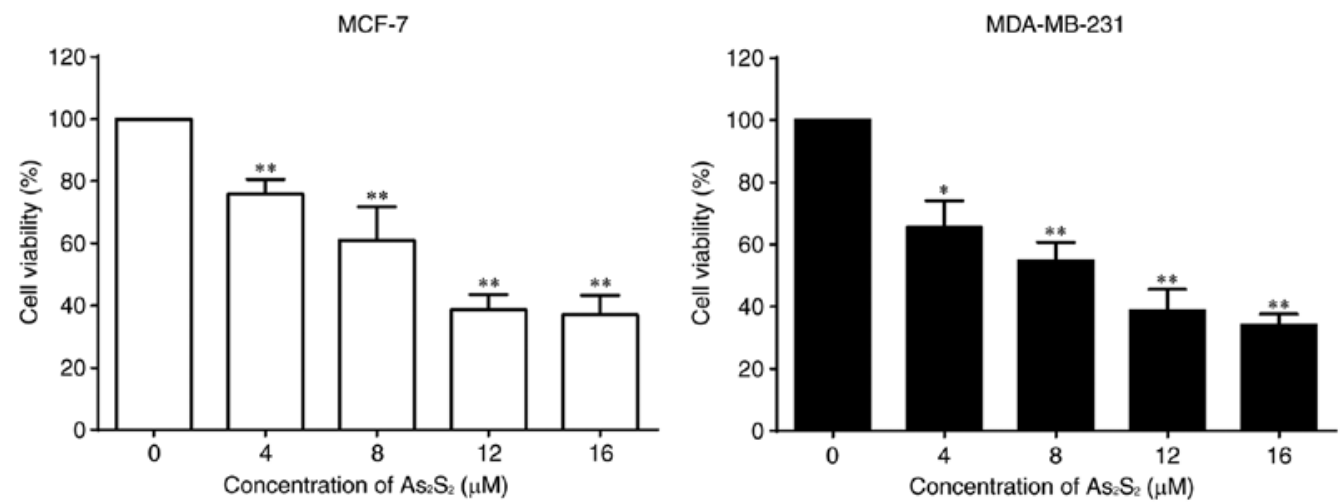

Figure 1. As $\mathrm{S}_{2}$ inhibits the viability of breast cancer cells. MCF-7 and MDA-MB-231 cells were treated with various concentrations $(0,4,8,12$ and $16 \mu \mathrm{M})$ of $\mathrm{As}_{2} \mathrm{~S}_{2}$ for $48 \mathrm{~h}$, and the cell viability was determined using Cell Counting Kit- 8 assays. Results are presented as the mean \pm standard error of the mean ( $\geq 3$ ). ${ }^{*} \mathrm{P}<0.05,{ }^{* *} \mathrm{P}<0.01$ vs. control group $\left(0 \mu \mathrm{M} \mathrm{As} \mathrm{S}_{2}\right)$.

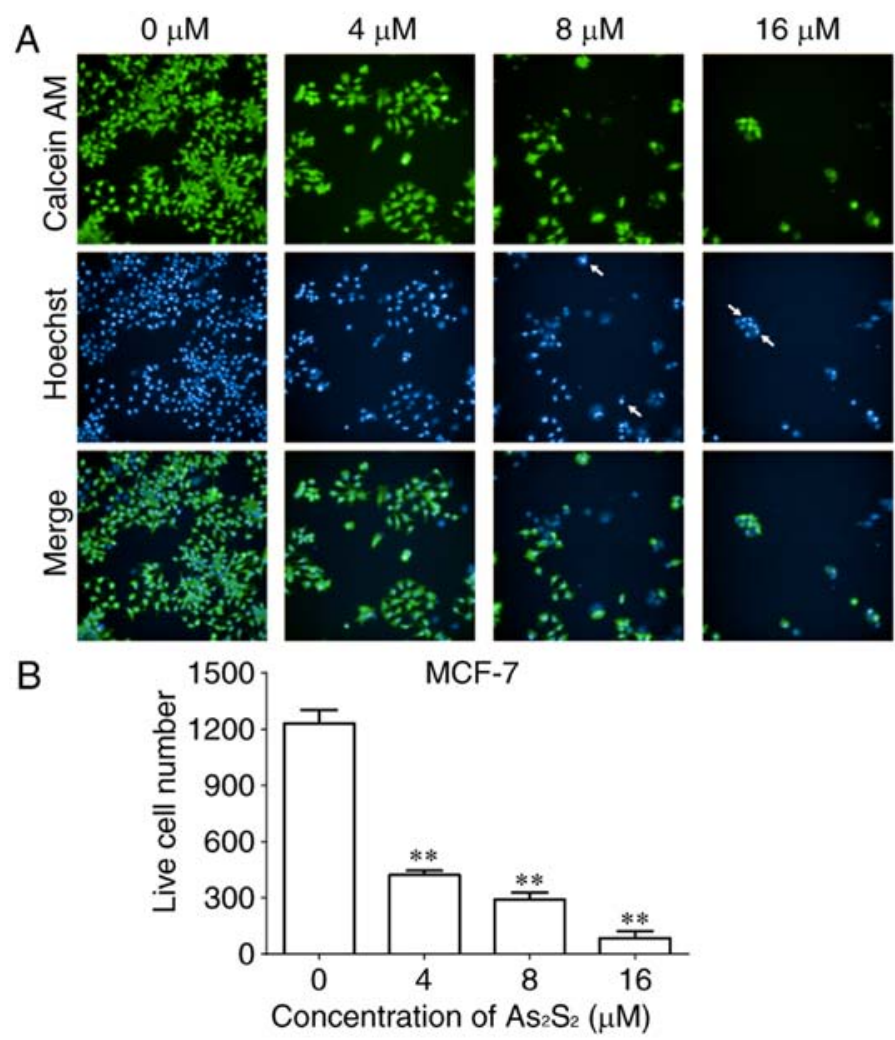

Figure 2. $\mathrm{As}_{2} \mathrm{~S}_{2}$ induces changes in calcein-AM and Hoechst 33342 staining in MCF-7 cells. MCF-7 cells were seeded at 5,000 cells/well. The cells were treated with serial concentrations of $\mathrm{As}_{2} \mathrm{~S}_{2}(0,4,8$ and $16 \mu \mathrm{M})$ for $48 \mathrm{~h}$. (A) Viable cells exposed to calcein-AM exhibited bright green fluorescence. Hoechst 33342 staining, as a nuclear counterstain, exhibited bright blue fluorescence. Cells with bright fragmented or condensed nuclei (arrows) were identified as those undergoing apoptosis. Merging of calcein-AM- and Hoechst 33342-stained cells exhibited cyan fluorescence. Images were captured and analyzed using a fluorescence microplate reader with a $\times 20$ objective (original magnification, x200). (B) Quantitative analysis of live MCF-7 cells. Results are presented as the mean \pm standard error of the mean $(\mathrm{n} \geq 3){ }^{* * *} \mathrm{P}<0.01$ vs. control group $\left(0 \mu \mathrm{MAs} \mathrm{S}_{2}\right)$. AM, acetoxymethyl ester.

MCF-7 and MDA-MB-231 cells were harvested, washed with PBS and resuspended in $500 \mu \mathrm{l}$ PBS. The intracellular ROS levels of the two cell lines were detected and analyzed using a flow cytometer and BD FACSDiva software.

Statistical analyses. Statistical analyses were performed using GraphPad Prism software (version 6.0; GraphPad Software, La Jolla, CA, USA). Results are presented as the mean \pm standard error of the mean of three or more independent experiments. A one-way analysis of variance followed by Tukey's post hoc test was used for multiple comparisons.
$\mathrm{P}<0.05$ was considered to indicate a statistically significant difference.

\section{Results}

$A s_{2} S_{2}$ inhibits the cell viability of breast cancer cells. MCF-7 and MDA-MB-231 cells were cultured in the presence of various concentrations of $\mathrm{As}_{2} \mathrm{~S}_{2}$ ranging between 0 and $16 \mu \mathrm{M}$ for $48 \mathrm{~h}$, and a CCK-8 assay was performed to determine cell viabilities. As presented in Fig. 1, $\mathrm{As}_{2} \mathrm{~S}_{2}$ inhibited the proliferation of the breast cancer cell lines MCF-7 and 

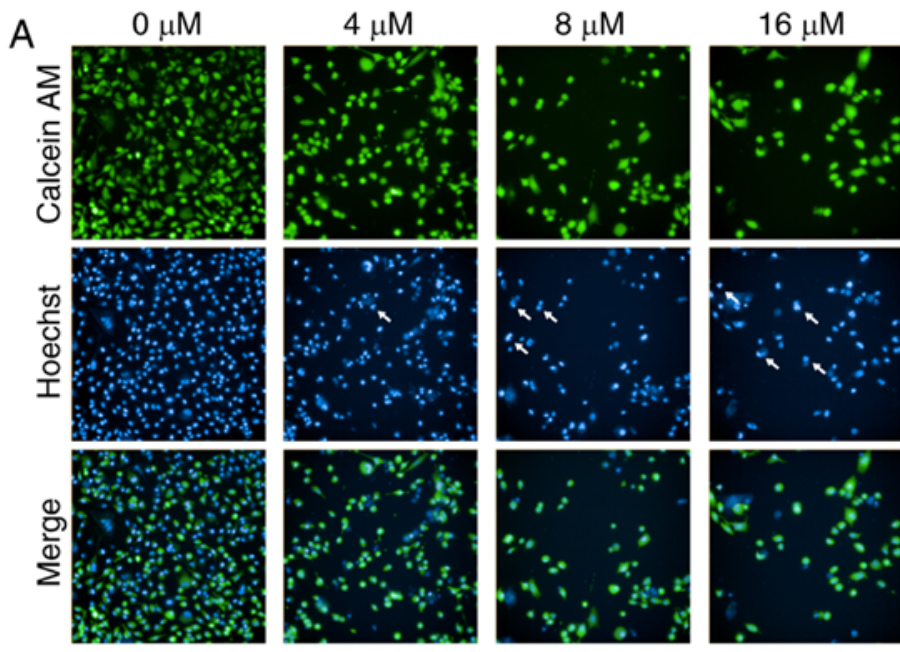

B

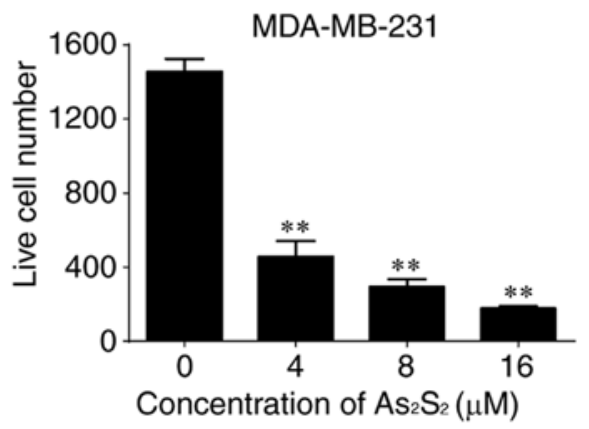

Figure 3. $\mathrm{As}_{2} \mathrm{~S}_{2}$ induces changes in calcein-AM and Hoechst 33342 staining in MDA-MB-231 cells. MDA-MB-231 cells were seeded at 5,000 cells/well. The cells were treated with serial concentrations of $\mathrm{As}_{2} \mathrm{~S}_{2}(0,4,8$ and $16 \mu \mathrm{M})$ for $48 \mathrm{~h}$. (A) Viable cells exposed to calcein-AM exhibited bright green fluorescence. Hoechst 33342 staining as a nuclear counterstain exhibited bright blue fluorescence. Cells with bright fragmented or condensed nuclei (arrows) were identified as those undergoing apoptosis. Merging of calcein-AM- and Hoechst 33332-stained cells exhibited cyan fluorescence. Images were captured and analyzed using a fluorescence microplate reader with a x20 objective (original magnification, x200). (B) Quantitative analysis of live MDA-MB-231 cells. Results are presented as the mean \pm standard error of the mean $(n \geq 3) .{ }^{* *} \mathrm{P}<0.01$ vs. control group $\left(0 \mu \mathrm{M} \mathrm{As}_{2} \mathrm{~S}_{2}\right)$. AM, acetoxymethyl ester.

MDA-MB-231 in a dose-dependent manner. The half-maximal inhibitory concentrations ( $\mathrm{IC}_{50}$ values) of $\mathrm{As}_{2} \mathrm{~S}_{2}$ in $\mathrm{MCF}-7$ and MDA-MB-231 cells were $11.75 \pm 1.99$ and $8.21 \pm 2.07 \mu \mathrm{M}$ after $48 \mathrm{~h}$ of exposure, respectively.

As an additional measurement to monitor cell growth inhibition induced by $\mathrm{As}_{2} \mathrm{~S}_{2}$ in breast cancer cells, the fluorescent dye calcein-AM was used to identify live cells (38). As presented in Figs. 2 and 3, live cell numbers in the two cell lines markedly decreased following treatment with increasing $\mathrm{As}_{2} \mathrm{~S}_{2}$ concentrations in a dose-dependent manner. In MCF-7 cells, compared with the control group $\left(0 \mu \mathrm{M} \mathrm{As}_{2} \mathrm{~S}_{2} ; 1,232.00 \pm 70.74\right.$ cells), the live cell number was significantly decreased to $422.00 \pm 22.87(\mathrm{P}<0.0001), 291.70 \pm 37.17 \quad(\mathrm{P}<0.0001)$ and $85.00 \pm 36.76(\mathrm{P}<0.0001)$ following exposure to 4,8 and $16 \mu \mathrm{M}$ $\mathrm{As}_{2} \mathrm{~S}_{2}$ for $48 \mathrm{~h}$, respectively (Fig. 2). In MDA-MB-231 cells, compared with the control group $\left(0 \mu \mathrm{M} \mathrm{As}_{2} \mathrm{~S}_{2} ; 1,455.00 \pm 68.75\right.$ cells), the live cell number was significantly decreased to

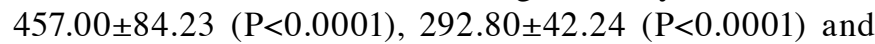
$177.00 \pm 11.92(\mathrm{P}<0.0001)$ following exposure to 4,8 and $16 \mu \mathrm{M}$ $\mathrm{As}_{2} \mathrm{~S}_{2}$ for $48 \mathrm{~h}$, respectively (Fig. 3).

$\mathrm{As}_{2} \mathrm{~S}_{2}$ inhibits the motility of breast cancer cells. A scratch assay was performed to assess the effect of $\mathrm{As}_{2} \mathrm{~S}_{2}$ on the motility of breast cancer cells. As presented in Fig. 4, with the dynamic observation at 0 and $48 \mathrm{~h}$ after scratching, $\mathrm{As}_{2} \mathrm{~S}_{2}$ treatment significantly inhibited migration of the two cell lines. In
MCF-7 cells, compared with the control group (0 $\left.\mu \mathrm{M} \mathrm{As}_{2} \mathrm{~S}_{2}\right)$, the relative migration rates significantly decreased following exposure to $8 \mu \mathrm{M}(\mathrm{P}=0.0177)$ and $16 \mu \mathrm{M}(\mathrm{P}=0.0042) \mathrm{As}_{2} \mathrm{~S}_{2}$. In MDA-MB-231 cells, compared with the control group $(0 \mu \mathrm{M}$ $\left.\mathrm{As}_{2} \mathrm{~S}_{2}\right)$, the relative migration rates significantly decreased following exposure to $8 \mu \mathrm{M}(\mathrm{P}<0.0001)$ and $16 \mu \mathrm{M}(\mathrm{P}<0.0001)$ $\mathrm{As}_{2} \mathrm{~S}_{2}$. These data indicate that $\mathrm{As}_{2} \mathrm{~S}_{2}$ inhibits the motility and invasion of different types of breast cancer cell.

In addition, the expression of the tumor migration- and invasion-associated protein MMP-9 was determined by western blot analysis. As presented in Fig. 5, $\mathrm{As}_{2} \mathrm{~S}_{2}$ treatment significantly decreased MMP-9 expression at concentrations of $8(\mathrm{P}=0.0446)$ and $16(\mathrm{P}=0.0233) \mu \mathrm{M}$ in $\mathrm{MCF}-7$ cells in comparison with the control. In contrast, in MDA-MB-231 cells, compared with the control, a statistically significant decrease in the MMP-9 expression occurred at $16 \mu \mathrm{M}$ $\mathrm{As}_{2} \mathrm{~S}_{2}(\mathrm{P}=0.0444)$. These results suggested that $\mathrm{As}_{2} \mathrm{~S}_{2}$ exposure decreased the motility of breast cancer cells due at least in part to its downregulation of MMP-9 signals.

$A s_{2} S_{2}$ triggers cell cycle arrest in breast cancer cells. The effect of $\mathrm{As}_{2} \mathrm{~S}_{2}$ on the cell cycle was assessed by evaluating the proportion of cells in each phase compared with the control in MCF-7 and MDA-MB-231 cells using PI staining and flow cytometry. The results indicated that $\mathrm{As}_{2} \mathrm{~S}_{2}$ mainly induced $\mathrm{G}_{2} / \mathrm{M}$ phase arrest in MCF-7 cells and MDA-MB-231 cells (Fig. 6). 
A
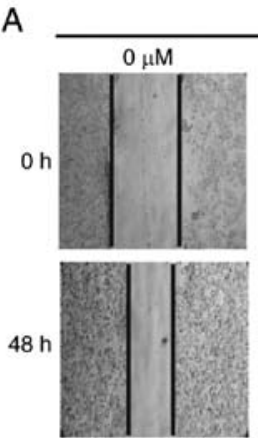

C

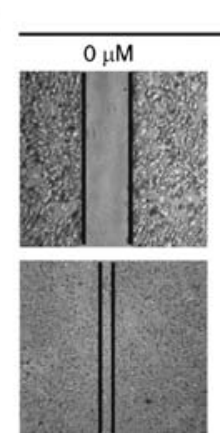

MCF-7
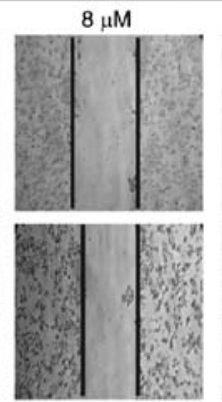

MDA-MB-231

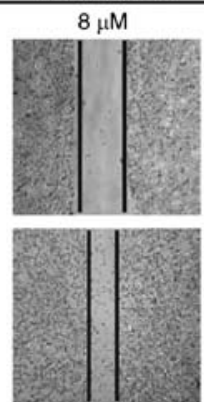

$16 \mu \mathrm{M}$
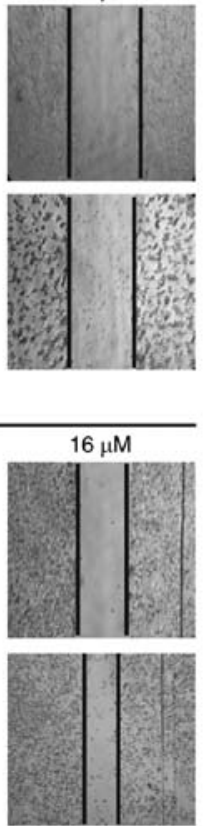

B

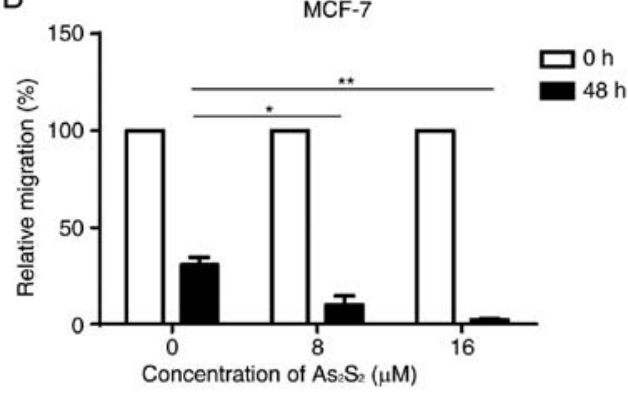

D

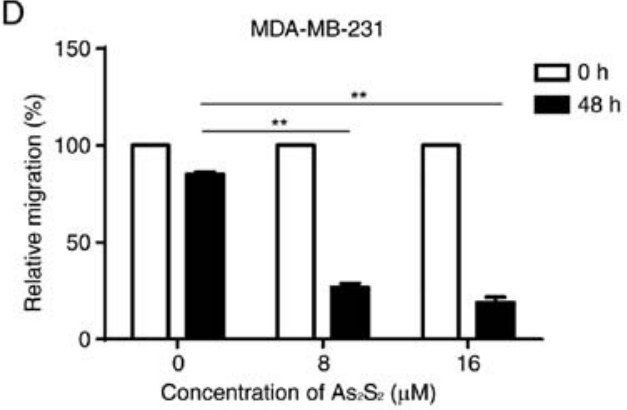

Figure 4. Inhibitory effects of $\mathrm{As}_{2} \mathrm{~S}_{2}$ on the migration of MCF-7 and MDA-MB-231 cells determined using a wound healing assay. MCF-7 and MDA-MB-231 cells were treated with various concentrations $(0,8$ and $16 \mu \mathrm{M})$ of $\mathrm{As}_{2} \mathrm{~S}_{2}$ for $48 \mathrm{~h}$, and then the wound areas were observed. (A) Representative images of wounded MCF-7 cells (magnification, x100). (B) Quantification of relative migration of MCF-7 cells. (C) Representative images of wounded MDA-MB-341 cells (magnification, $x 100$ ). (D) Quantification of relative migration of MDA-MB-341 cells. Results are presented as the mean \pm standard error of the mean $(\mathrm{n} \geq 3) .{ }^{*} \mathrm{P}<0.05,{ }^{* *} \mathrm{P}<0.01$ vs. control $\left(0 \mu \mathrm{M} \mathrm{As} \mathrm{S}_{2}\right)$.
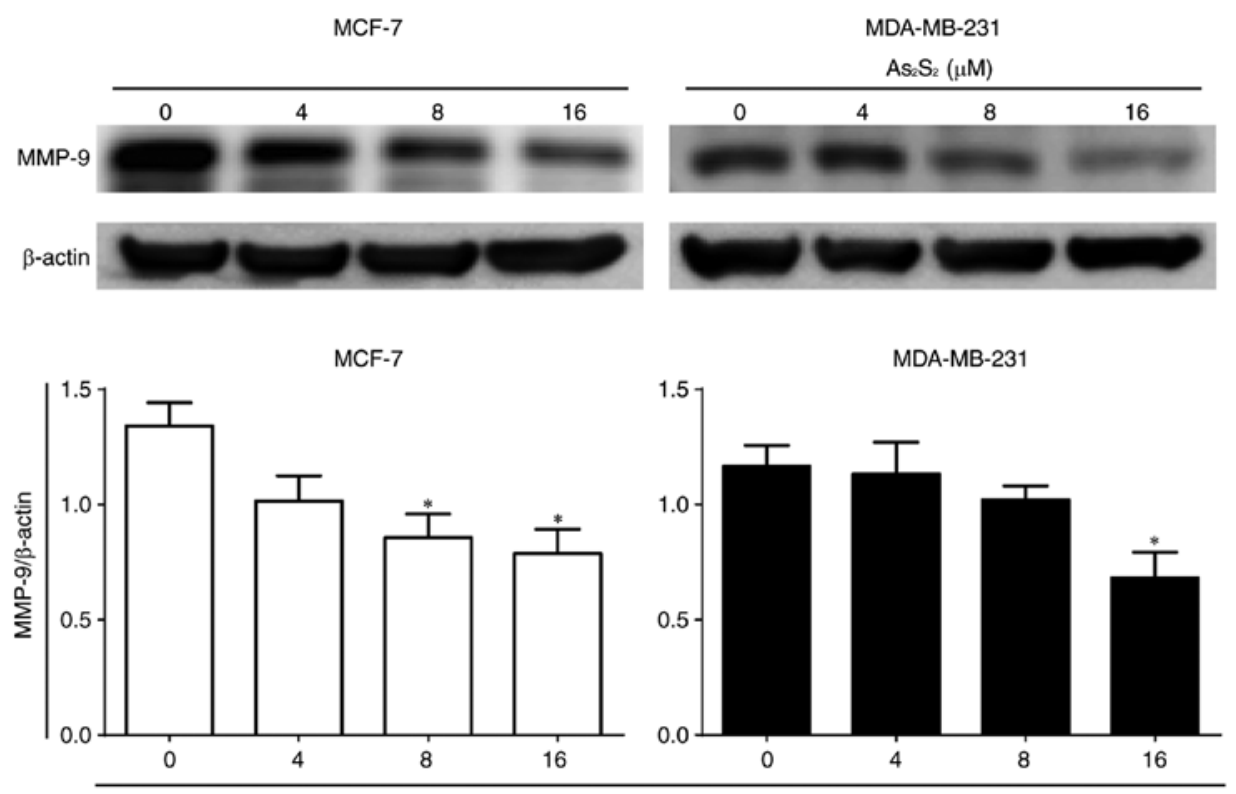

Concentration of $\mathrm{As}_{2} \mathrm{~S}_{2}(\mu \mathrm{M})$

Figure 5. Effects of $\mathrm{As}_{2} \mathrm{~S}_{2}$ on the protein expression of MMP-9 in breast cancer cells. MCF-7 and MDA-MB-231 cells were treated with different concentrations of $\mathrm{As}_{2} \mathrm{~S}_{2}(0,4,8$ and $16 \mu \mathrm{M})$ for $48 \mathrm{~h}$. Western blot assays were performed to examine the effects of As $\mathrm{S}_{2}$ on the expression of MMP-9 in the two cell lines after $48 \mathrm{~h}$ of treatment. $\beta$-actin was used as an internal control. All images are representative of three independent analyses from three independent cellular preparations. * $\mathrm{P}<0.05$ vs. control $\left(0 \mu \mathrm{M} \mathrm{As}_{2} \mathrm{~S}_{2}\right)$.

In MCF-7 cells, following exposure to $\mathrm{As}_{2} \mathrm{~S}_{2}$ at different concentrations $(4,8$ and $16 \mu \mathrm{M})$ for $48 \mathrm{~h}$, the proportion of cells in $\mathrm{G}_{2} / \mathrm{M}$ phase significantly increased from $4.00 \pm 0.75(0 \mu \mathrm{M})$ to $8.81 \pm 0.52(\mathrm{P}=0.0003), 9.69 \pm 0.06(\mathrm{P}<0.0001)$ and $12.05 \pm 0.31 \%(\mathrm{P}<0.0001)$, respectively. In MDA-MB-231 cells, $\mathrm{As}_{2} \mathrm{~S}_{2}$ treatment at 4,8 and $16 \mu \mathrm{M}$ for $48 \mathrm{~h}$ increased the proportion of cells in $\mathrm{G}_{2} / \mathrm{M}$ phase from $16.34 \pm 0.44(0 \mu \mathrm{M})$ to $22.64 \pm 0.33(\mathrm{P}=0.0001), 26.11 \pm 0.30(\mathrm{P}<0.0001)$ and $43.43 \pm 1.11 \%(\mathrm{P}<0.0001)$, respectively, as well as increased the proportion of cells in $\mathrm{S}$ phase from $20.40 \pm 0.18(0 \mu \mathrm{M})$ 
A

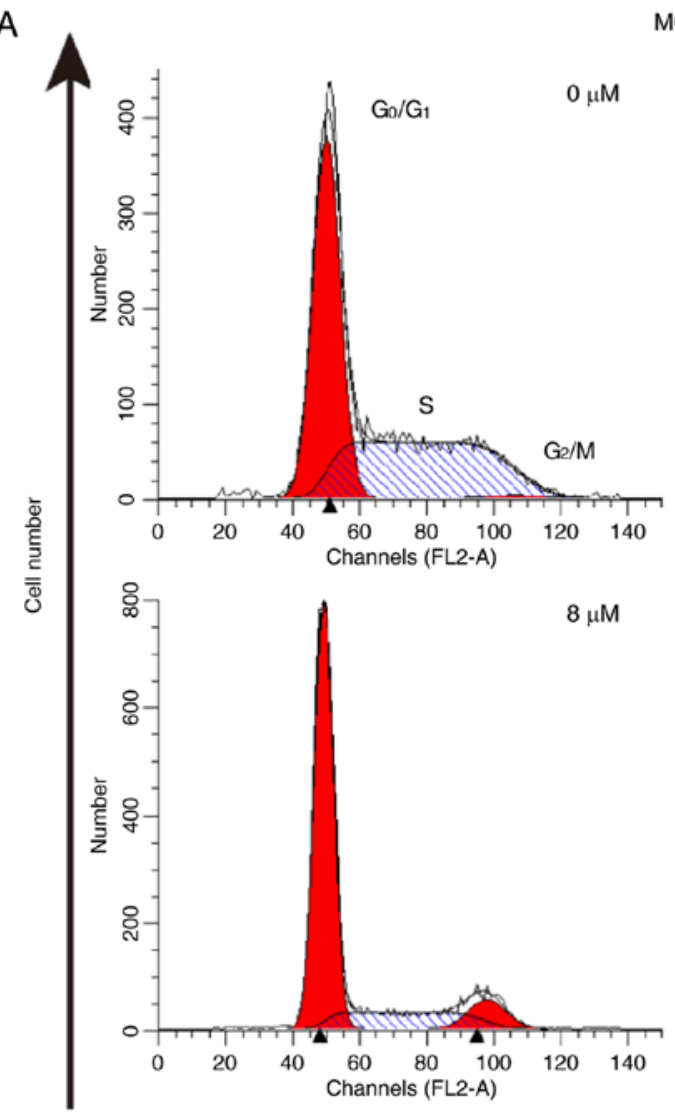

MCF-7
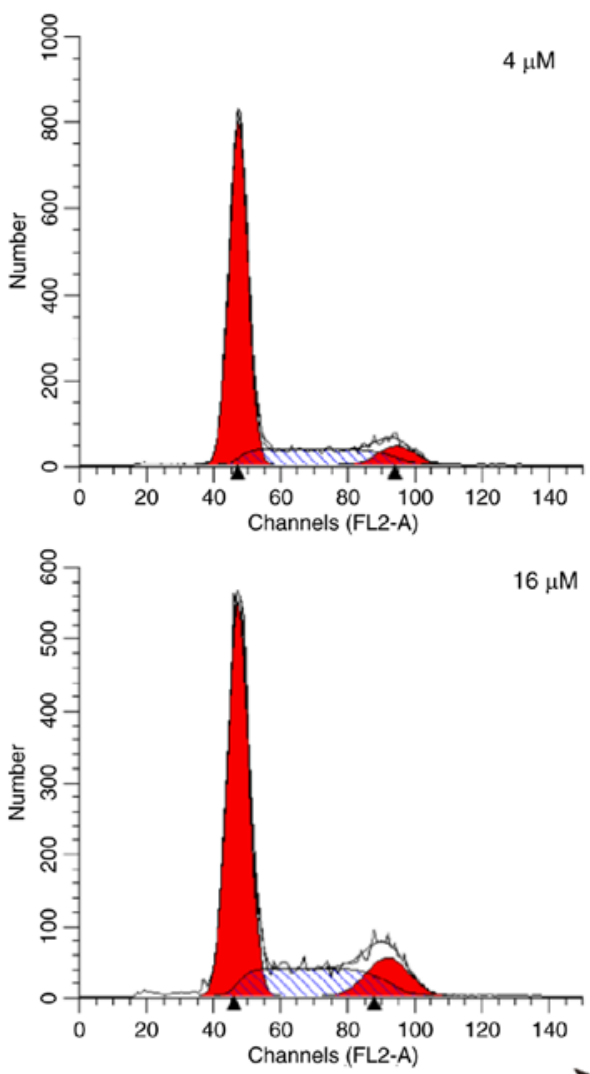

DNA content

B

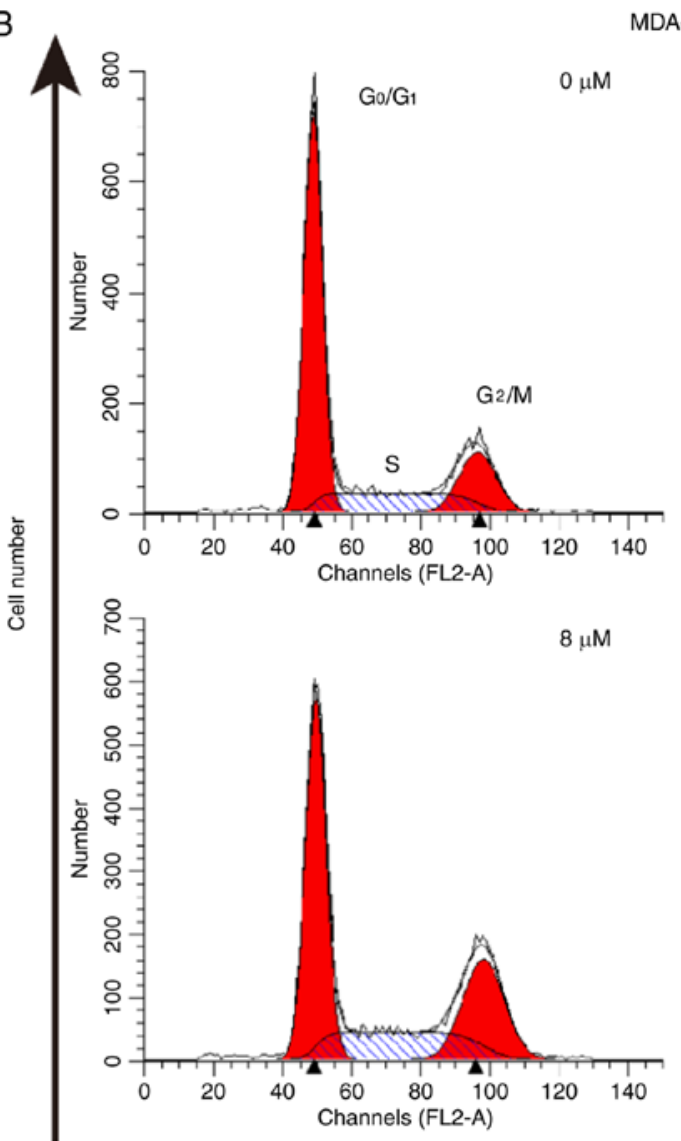

MDA-MB-231
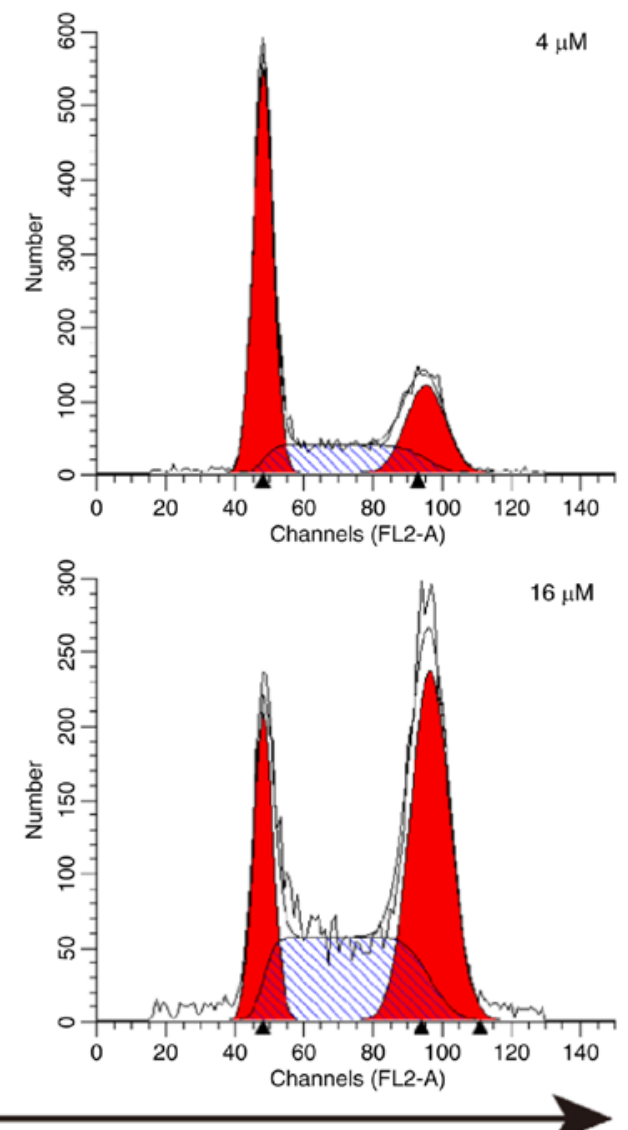

DNA content

Figure 6. $\mathrm{As}_{2} \mathrm{~S}_{2}$ triggers cell cycle arrest in breast cancer cells. (A) MCF-7 and (B) MDA-MB-231 cells were treated with various concentrations of As $\mathrm{S}_{2}(0,4$, 8 and $16 \mu \mathrm{M}$ ) for $48 \mathrm{~h}$. The peaks represent $\mathrm{G}_{0} / \mathrm{G}_{1}, \mathrm{~S}$ and $\mathrm{G}_{2} / \mathrm{M}$ phases in the cell cycle. 

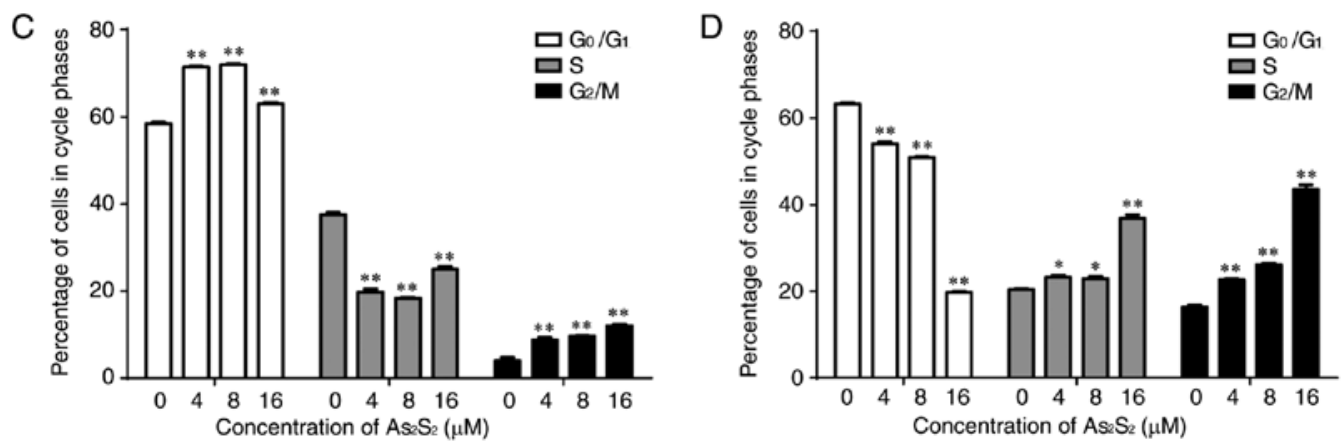

Figure 6. Continued. Quantification of the proportions of cells in a given phase of the cell cycle in (C) MCF-7 and (D) MDA-MB-231 cells after $48 \mathrm{~h}$ of treatment. Results are expressed as the mean \pm standard error of the mean $(\mathrm{n} \geq 3) .{ }^{*} \mathrm{P}<0.05,{ }^{* * *} \mathrm{P}<0.01$ vs. control $\left(0 \mu \mathrm{M} \mathrm{As}_{2} \mathrm{~S}_{2}\right)$.

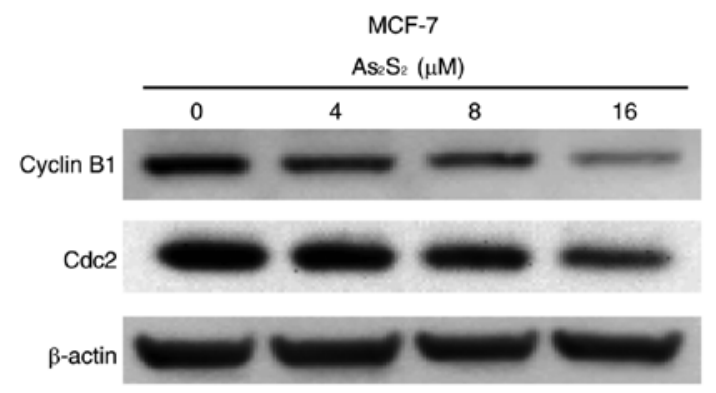

MCF-7
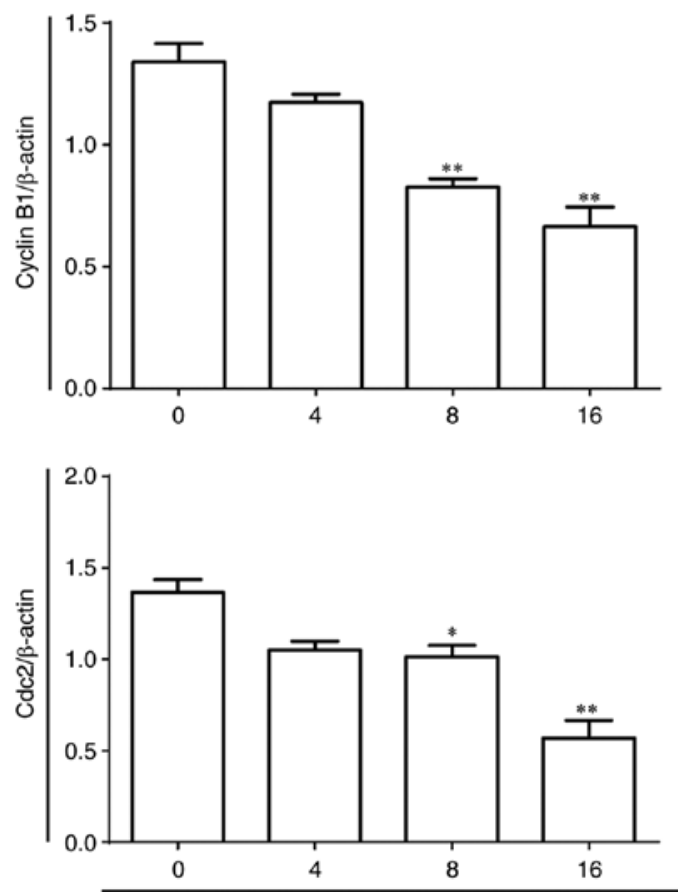

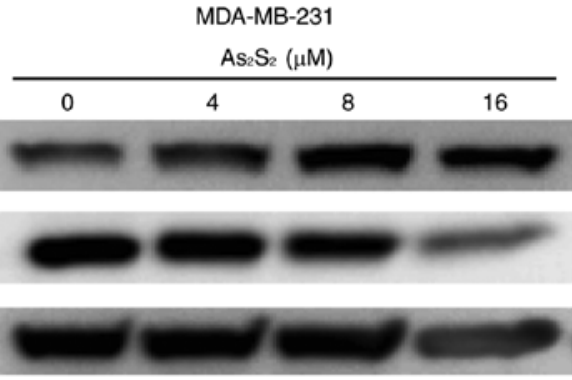

MDA-MB-231
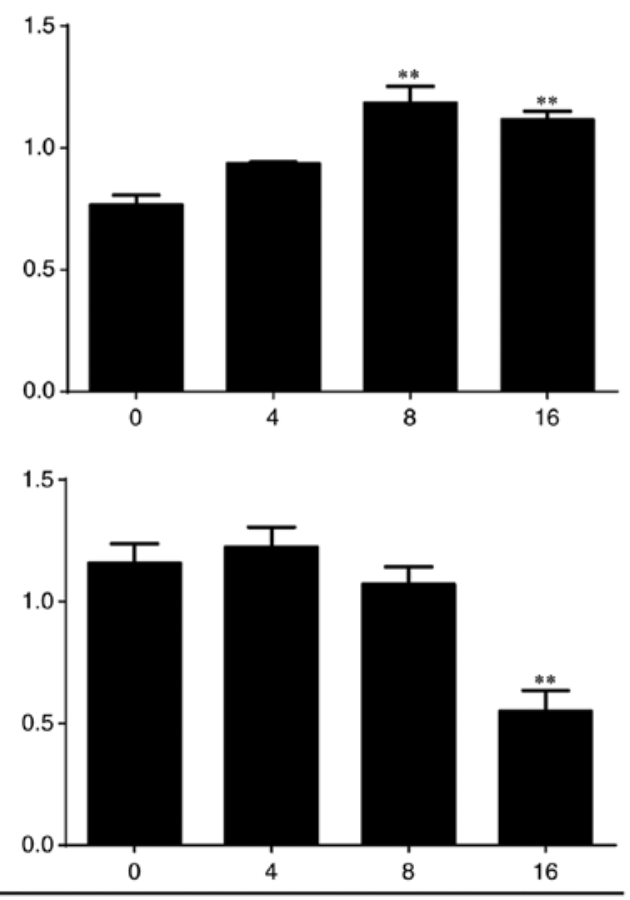

Concentration of $\mathrm{As} 2 \mathrm{~S}_{2} \mathrm{As}_{2} \mathrm{~S}_{2}(\mu \mathrm{M})$

Figure 7. Effects of $\mathrm{As}_{2} \mathrm{~S}_{2}$ on cell cycle regulators in breast cancer cells. MCF-7 and MDA-MB-231 cells were cultured with various concentrations of As $\mathrm{S}_{2}$ $(0,4,8$ and $16 \mu \mathrm{M})$ for $48 \mathrm{~h}$, and western blot assays were performed to examine the effects of $\mathrm{As}_{2} \mathrm{~S}_{2}$ on the expression of the key proteins cyclin $\mathrm{B} 1$ and Cdc2 in the two cell lines after $48 \mathrm{~h}$ of treatment. $\beta$-actin was used as an internal control. All images are representative of three independent analyses from three independent cellular preparations. ${ }^{*} \mathrm{P}<0.05,{ }^{* *} \mathrm{P}<0.01$ vs. control $\left(0 \mu \mathrm{M} \mathrm{As} \mathrm{S}_{2}\right)$.

to $23.25 \pm 0.51 \quad(\mathrm{P}=0.0242), 22.94 \pm 0.47 \quad(\mathrm{P}=0.0451)$ and $36.81 \pm 0.87 \%(\mathrm{P}<0.0001)$, respectively.

Furthermore, the expression of cell cycle-associated proteins was determined by western blot analysis. As presented in Fig. 7, compared with the control, the expression of cyclin B1 significantly decreased following $\mathrm{As}_{2} \mathrm{~S}_{2}$ treatment at concentrations of
$8(\mathrm{P}=0.0014)$ and $16(\mathrm{P}=0.0002) \mu \mathrm{M}$ in MCF-7 cells, but increased with $\mathrm{As}_{2} \mathrm{~S}_{2}$ at concentrations of $8(\mathrm{P}=0.0007)$ and $16(\mathrm{P}=0.0022)$ $\mu \mathrm{M}$ in MDA-MB-231 cells. Following exposure to $\mathrm{As}_{2} \mathrm{~S}_{2}$ for $48 \mathrm{~h}$, a statistically significant decrease in the expression of Cdc2 occurred in MCF-7 cells treated with $8 \mu \mathrm{M} \mathrm{As}_{2} \mathrm{~S}_{2}(\mathrm{P}=0.0348)$ and in MDA-MB-231 cells treated with $16 \mu \mathrm{M} \mathrm{As}_{2} \mathrm{~S}_{2}(\mathrm{P}=0.0028)$. 
A MCF-7
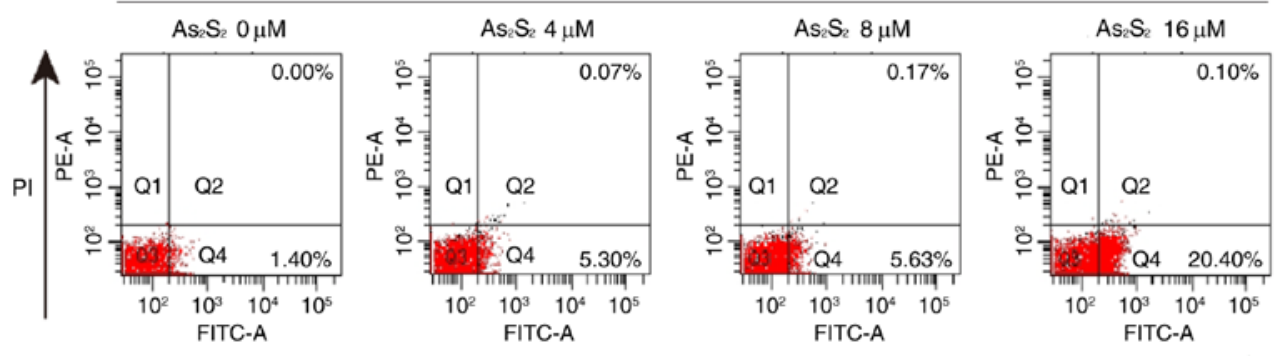

Annexin V

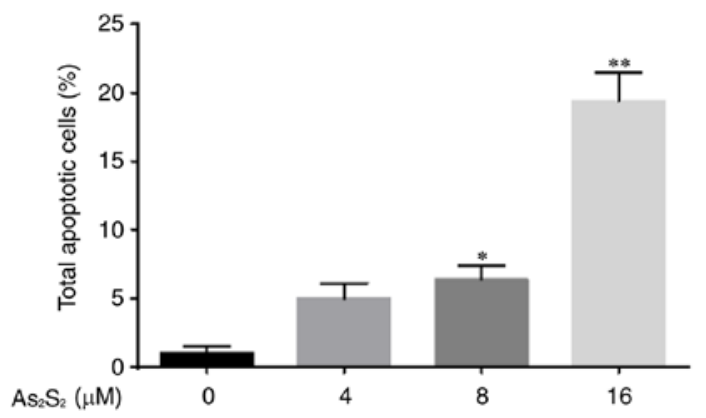

B
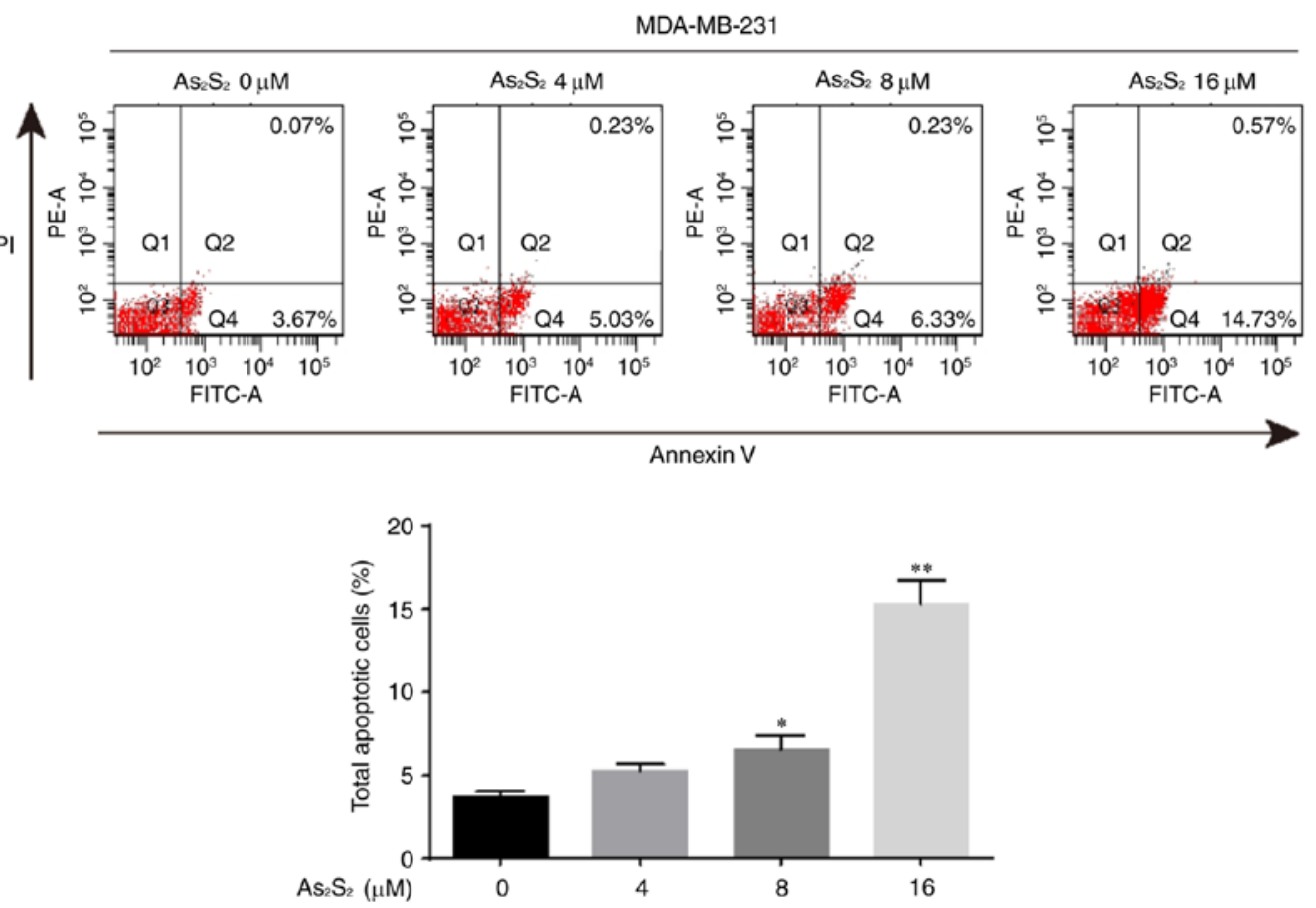

Figure 8. $\mathrm{As}_{2} \mathrm{~S}_{2}$ induces apoptosis in breast cancer cells. (A) MCF-7 and (B) MDA-MB-231 cells were treated with different concentrations of As $\mathrm{S}_{2}(0,4,8$ and $16 \mu \mathrm{M})$ for $48 \mathrm{~h}$, followed by staining with Annexin V/PI, and then analyzed by flow cytometry. The cells were assessed for the total number of apoptotic cells, including early-apoptotic (Annexin $\left.\mathrm{V}^{+} / \mathrm{PI}\right)$ and late-apoptotic (Annexin $\mathrm{V}^{+} / \mathrm{PI}^{+}$) cells. Results are expressed as the mean \pm standard error of the mean $(\mathrm{n} \geq 3$ ). ${ }^{*} \mathrm{P}<0.05,{ }^{* *} \mathrm{P}<0.01$ vs. control $\left(0 \mu \mathrm{M} \mathrm{As}_{2} \mathrm{~S}_{2}\right)$. PI, propidium iodide; $\mathrm{PE}$, phycoerythrin.

These results indicated that $\mathrm{As}_{2} \mathrm{~S}_{2}$ triggers $\mathrm{G}_{2} / \mathrm{M}$ phase arrest in MCF-7 and MDA-MB-231 cells by regulating the expression of cell cycle-associated proteins.

$A s_{2} S_{2}$ induces apoptosis in breast cancer cells. Apoptosis induced by $\mathrm{As}_{2} \mathrm{~S}_{2}$ in MCF-7 and MDA-MB-231 was validated using Hoechst 33342 staining and a flow cytometric assay.

As presented in Figs. 2 and 3, the occurrence of typical apoptotic characteristics, such as cell shrinkage, chromatin condensation and nuclei fragmentation (39), was evident in MCF-7 and MDA-MB-231 cells following treatment with $\mathrm{As}_{2} \mathrm{~S}_{2}(8$ and $16 \mu \mathrm{M})$ for $48 \mathrm{~h}$, whereas normal nuclei manifested with a round shape and homogeneous staining.

The induction of apoptosis was investigated further using an Annexin V/PI double-staining assay followed by flow cytometry, which was based on a probe of the total proportion of apoptotic breast cancer cells (Annexin V-positive cells). As presented in Fig. 8, the total proportion of apoptotic 


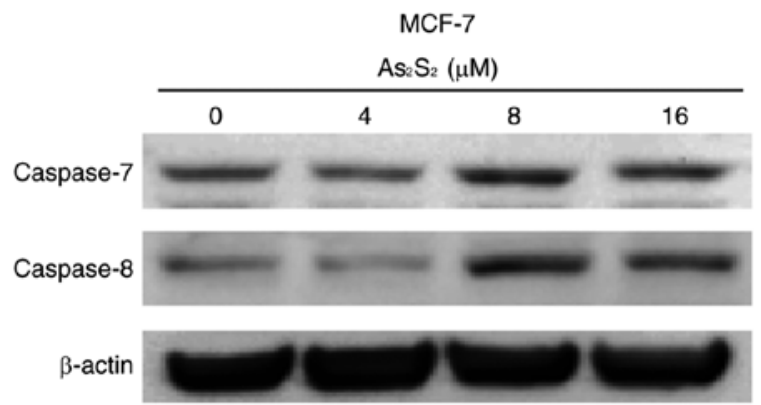

MCF-7
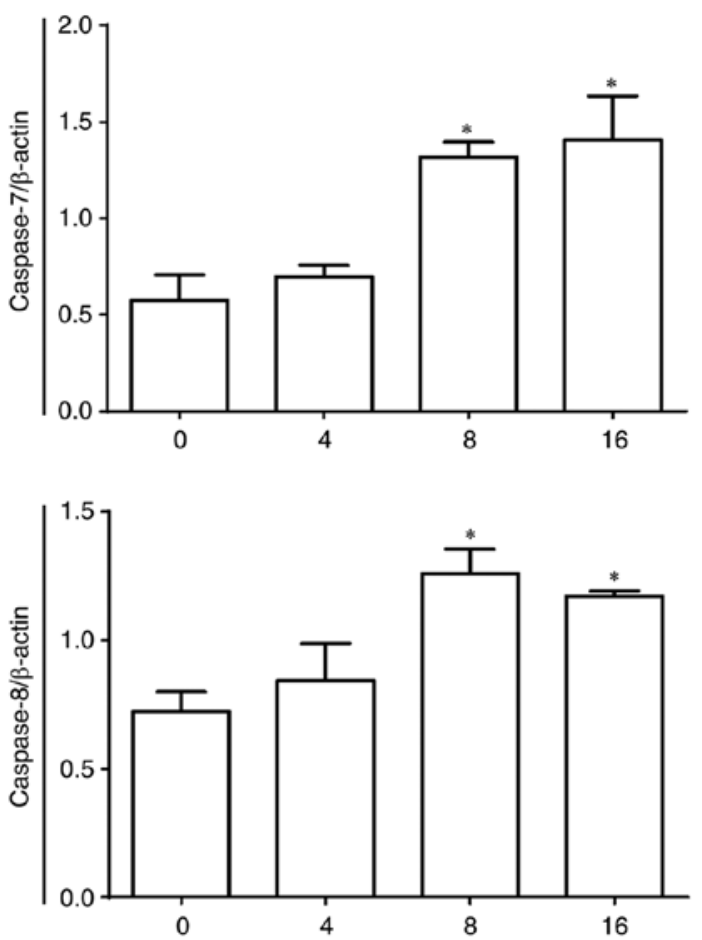
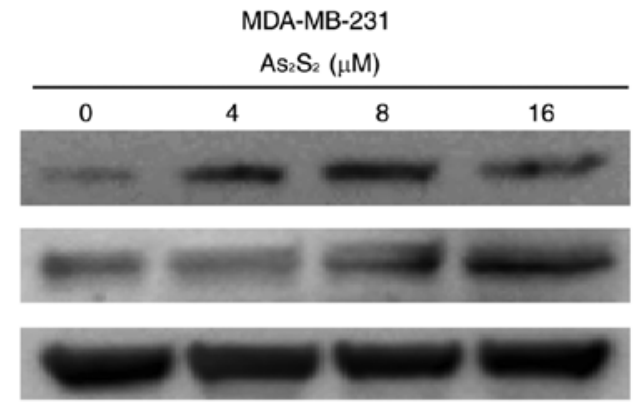

MDA-MB-231
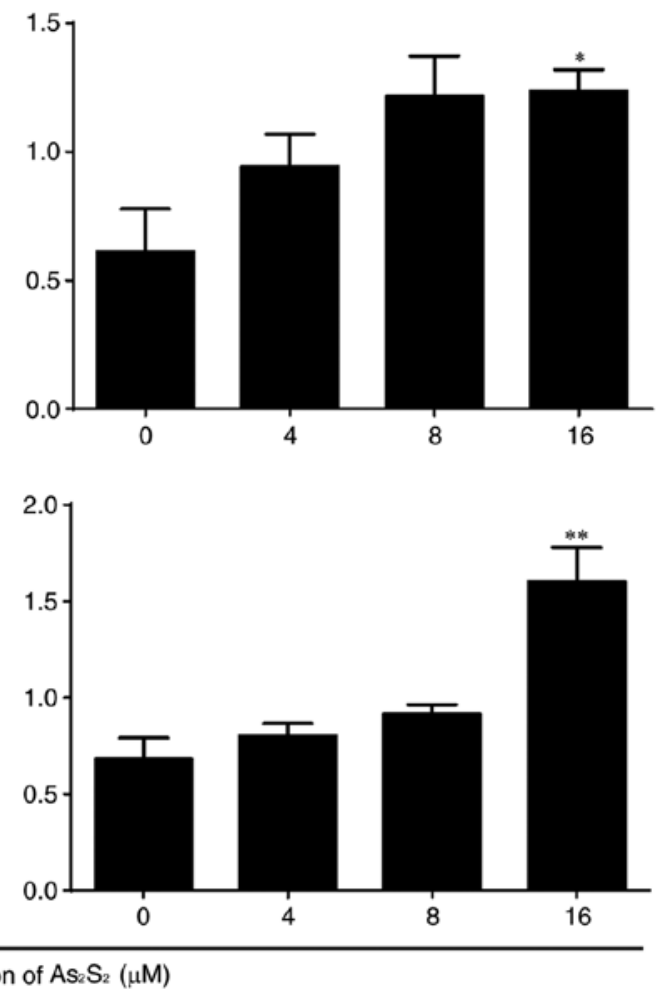

Figure 9. Effects of $\mathrm{As}_{2} \mathrm{~S}_{2}$ on the protein expression of caspase in breast cancer cells. MCF-7 and MDA-MB-231 cells were treated with different concentrations of $\mathrm{As}_{2} \mathrm{~S}_{2}(0,4,8$ and $16 \mu \mathrm{M})$ for $48 \mathrm{~h}$. Western blot assays were performed to examine the effects of $\mathrm{As}_{2} \mathrm{~S}_{2}$ on the expression of caspase-7 and -8 in the two cell lines after $48 \mathrm{~h}$ of treatment. $\beta$-actin was used as an internal control. All images are representative of three independent analyses from three independent cellular preparations. ${ }^{*} \mathrm{P}<0.05,{ }^{* *} \mathrm{P}<0.01$ vs. control $\left(0 \mu \mathrm{M} \mathrm{As}{ }_{2} \mathrm{~S}_{2}\right)$.

MCF-7 cells significantly increased from $1.05 \pm 0.48$ for the control $\left(0 \mu \mathrm{M} \mathrm{As}_{2} \mathrm{~S}_{2}\right)$ to $6.35 \pm 1.05\left(8 \mu \mathrm{M} \mathrm{As}_{2} \mathrm{~S}_{2} ; \mathrm{P}=0.0307\right)$ and $19.40 \pm 2.03 \%\left(16 \mu \mathrm{M} \mathrm{As}_{2} \mathrm{~S}_{2} ; \mathrm{P}<0.0001\right)$ following exposure to $\mathrm{As}_{2} \mathrm{~S}_{2}$ for $48 \mathrm{~h}$. In MDA-MB-231 cells (Fig. 7), the proportion of apoptotic cells significantly increased from $3.73 \pm 0.32$ for the control $\left(0 \mu \mathrm{M} \mathrm{As}_{2} \mathrm{~S}_{2}\right)$ to $6.57 \pm 0.84\left(8 \mu \mathrm{M} \mathrm{As}_{2} \mathrm{~S}_{2} ; \mathrm{P}=0.0345\right)$ and $15.30 \pm 1.40 \%\left(16 \mu \mathrm{M} \mathrm{As}_{2} \mathrm{~S}_{2} ; \mathrm{P}<0.0001\right)$ following exposure to $\mathrm{As}_{2} \mathrm{~S}_{2}$ for $48 \mathrm{~h}$.

To further confirm the induction of apoptosis by $\mathrm{As}_{2} \mathrm{~S}_{2}$ in breast cancer cells, a western blot analysis was performed to investigate the expression of apoptosis-associated proteins. As presented in Fig. 9, the expression of pro-apoptotic proteins, such as caspase-8 (apoptotic initiator) and -7 (apoptotic executioner), was identified to be increased following treatment with $\mathrm{As}_{2} \mathrm{~S}_{2}$ in a dose-dependent manners in MCF-7 and MDA-MB-231 cells. Compared with the control, the expression of caspase-7 and -8 in MCF-7 cells was significantly increased after $48 \mathrm{~h}$ of treatment with $\mathrm{As}_{2} \mathrm{~S}_{2}$ at $8(\mathrm{P}=0.0234$ for caspase- $7 ; \mathrm{P}=0.0158$ for caspase- 8$)$ and $16(\mathrm{P}=0.0129$ for caspase-7; $\mathrm{P}=0.0391$ for caspase-8) $\mu \mathrm{M}$. In MDA-MB-231 cells, the expression of caspase-7 and -8 was also significantly increased after $48 \mathrm{~h}$ of treatment with $\mathrm{As}_{2} \mathrm{~S}_{2}$ at $16 \mu \mathrm{M}(\mathrm{P}=0.0294$ for caspase-7; $\mathrm{P}=0.0018$ for caspase-8).

As presented in Fig. 10, the ratio of Bax expression to Bcl-2 expression was increased by $\mathrm{As}_{2} \mathrm{~S}_{2}$ in MCF-7 and MDA-MB-231 cells. Compared with the control, significant increases were observed in MCF-7 cells following treatment with $8(\mathrm{P}=0.0003)$ and $16(\mathrm{P}<0.0001) \mu \mathrm{M} \mathrm{As}{ }_{2} \mathrm{~S}_{2}$ for $48 \mathrm{~h}$. In MDA-MB-231 cells, the ratio of Bax to Bcl-2 increased with increasing doses, although the change was not statistically significant. The anti-apoptotic protein $\mathrm{Bcl}-\mathrm{xl}$ was inhibited by $\mathrm{As}_{2} \mathrm{~S}_{2}$ in MCF-7 and MDA-MB-231 cells. Compared with the control, the expression of $\mathrm{Bcl}-\mathrm{xl}$ was significantly decreased by $\mathrm{As}_{2} \mathrm{~S}_{2}$ at $16 \mu \mathrm{M}$ in the two cell lines $(\mathrm{P}=0.0014$ in MCF-7 cells; $\mathrm{P}=0.0015$ in MDA-MB-231 cells). 


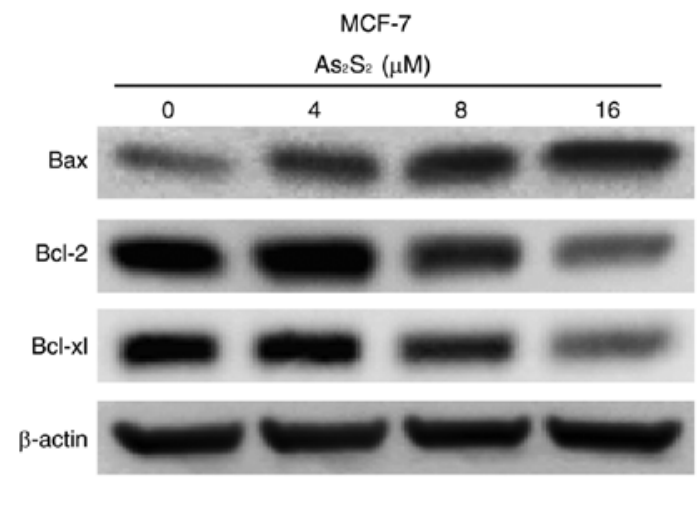

MCF-7
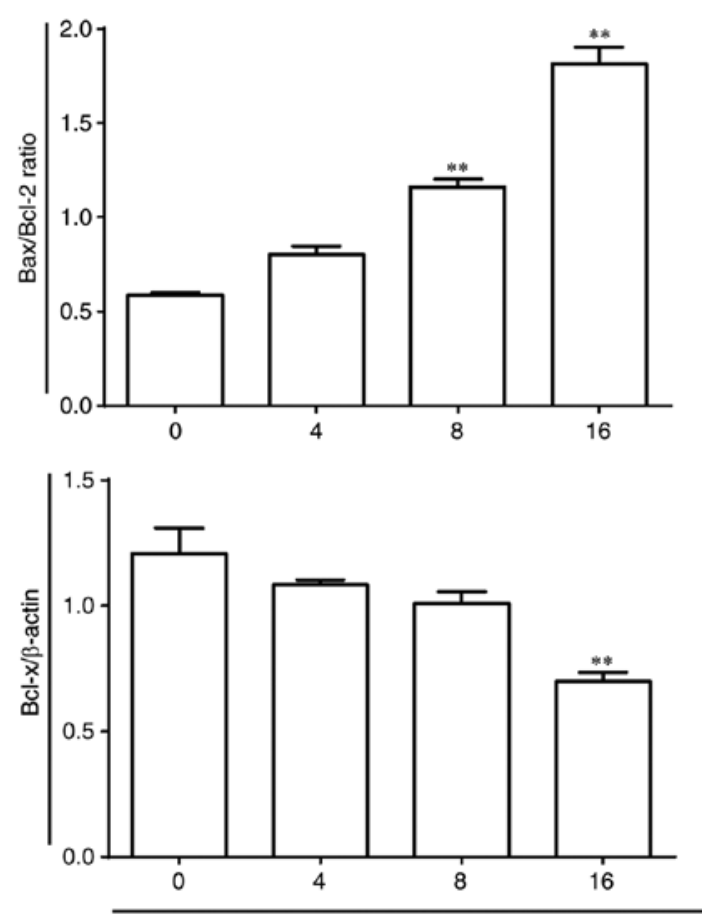

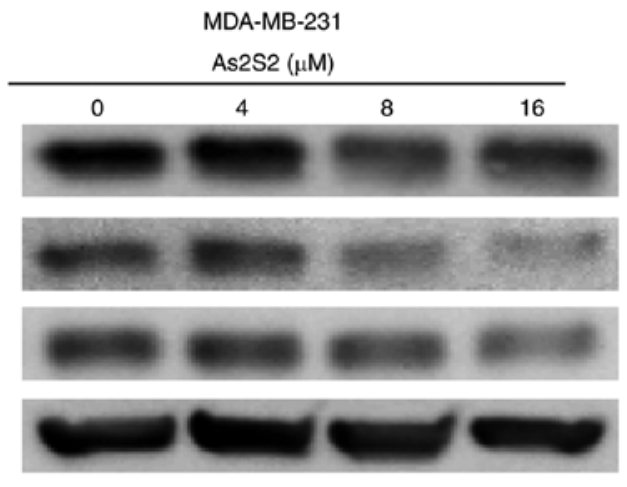

MDA-MB-231
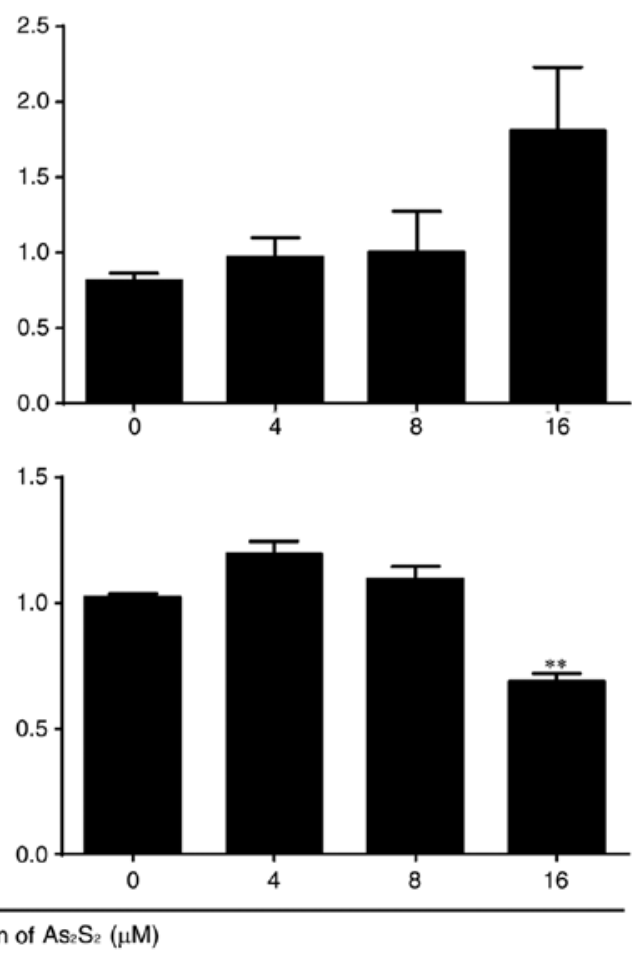

Figure 10. Effects of $\mathrm{As}_{2} \mathrm{~S}_{2}$ on the expression of Bcl-2 family proteins in breast cancer cells. MCF-7 and MDA-MB-231 cells were treated with different concentrations of $\mathrm{As}_{2} \mathrm{~S}_{2}(0,4,8$ and $16 \mu \mathrm{M})$ for $48 \mathrm{~h}$. Western blot assays were performed to determine the effects of As $\mathrm{S}_{2}$ on the expression of Bax, Bcl-2 and Bcl-xl in the two cell lines after $48 \mathrm{~h}$ of treatment. $\beta$-actin was used as an internal control. All images are representative of three independent analyses from three independent cellular preparations. ${ }^{* *} \mathrm{P}<0.01$ vs. control $\left(0 \mu \mathrm{M} \mathrm{As} \mathrm{S}_{2}\right)$. Bcl-2, B-cell lymphoma 2; Bax, Bcl-2-associated $\mathrm{X}$ protein; Bcl-xl, B-cell lymphoma extra-large.

Taken together, these results indicate that apoptosis was induced by $\mathrm{As}_{2} \mathrm{~S}_{2}$ in MCF-7 and MDA-MB-231 cells in a dose-dependent manner by regulating apoptosis-associated proteins.

$A s_{2} S_{2}$ induces autophagy in breast cancer cells. When autophagy is induced, LC3 is converted from the cytoplasmic form LC3-I into the membrane-associated form LC3-II. The ratio of LC3-II/LC3-I is widely considered as a primary marker of autophagy activation $(40,41)$.

As presented in Fig. 11, $\mathrm{As}_{2} \mathrm{~S}_{2}$ induced an increase in the LC3-II/LC3-I ratio in MCF-7 and MDA-MB-231 cells. Compared with the control, significant increases were observed in MCF-7 cells following treatment with $\mathrm{As}_{2} \mathrm{~S}_{2}$ at $8(\mathrm{P}=0.0007)$ and $16(\mathrm{P}=0.0187) \mu \mathrm{M}$. Similarly, the ratio of LC3-II/LC3-I was increased markedly in MDA-MB-231 cells following treatment with $\mathrm{As}_{2} \mathrm{~S}_{2}$ at $8(\mathrm{P}=0.0048)$ and $16(\mathrm{P}=0.0358) \mu \mathrm{M}$.
Autophagy has been identified to serve functions in cytoprotective and cytotoxic processes. To examine the effect of $\mathrm{As}_{2} \mathrm{~S}_{2}$-induced autophagy on breast cancer cell viability, MCF-7 and MDA-MB-231 cells were exposed to the autophagy inhibitor CQ in the presence of different concentrations of $\mathrm{As}_{2} \mathrm{~S}_{2}(0,4,8$ and $16 \mu \mathrm{M})$. As presented in Fig. 12A, inhibition of autophagy did not alter the inhibitory effect of $\mathrm{As}_{2} \mathrm{~S}_{2}$ on MCF-7 cells. Furthermore, although pretreatment with CQ significantly reversed the cell death induced by $\mathrm{As}_{2} \mathrm{~S}_{2}$ at $4 \mu \mathrm{M}(\mathrm{P}=0.0021)$ in MDA-MB-231 cells, no additional effect was observed in the presence of $\mathrm{As}_{2} \mathrm{~S}_{2}$ treatment at 8 or $16 \mu \mathrm{M}$ (Fig. 12B).

Effects of $\mathrm{As}_{2} \mathrm{~S}_{2}$ on ROS production in breast cancer cells. The effects of $\mathrm{As}_{2} \mathrm{~S}_{2}$ on ROS production in breast cancer cells were assessed using an ROS-sensitive probe, DCF-DA, and a flow cytometric assay. 

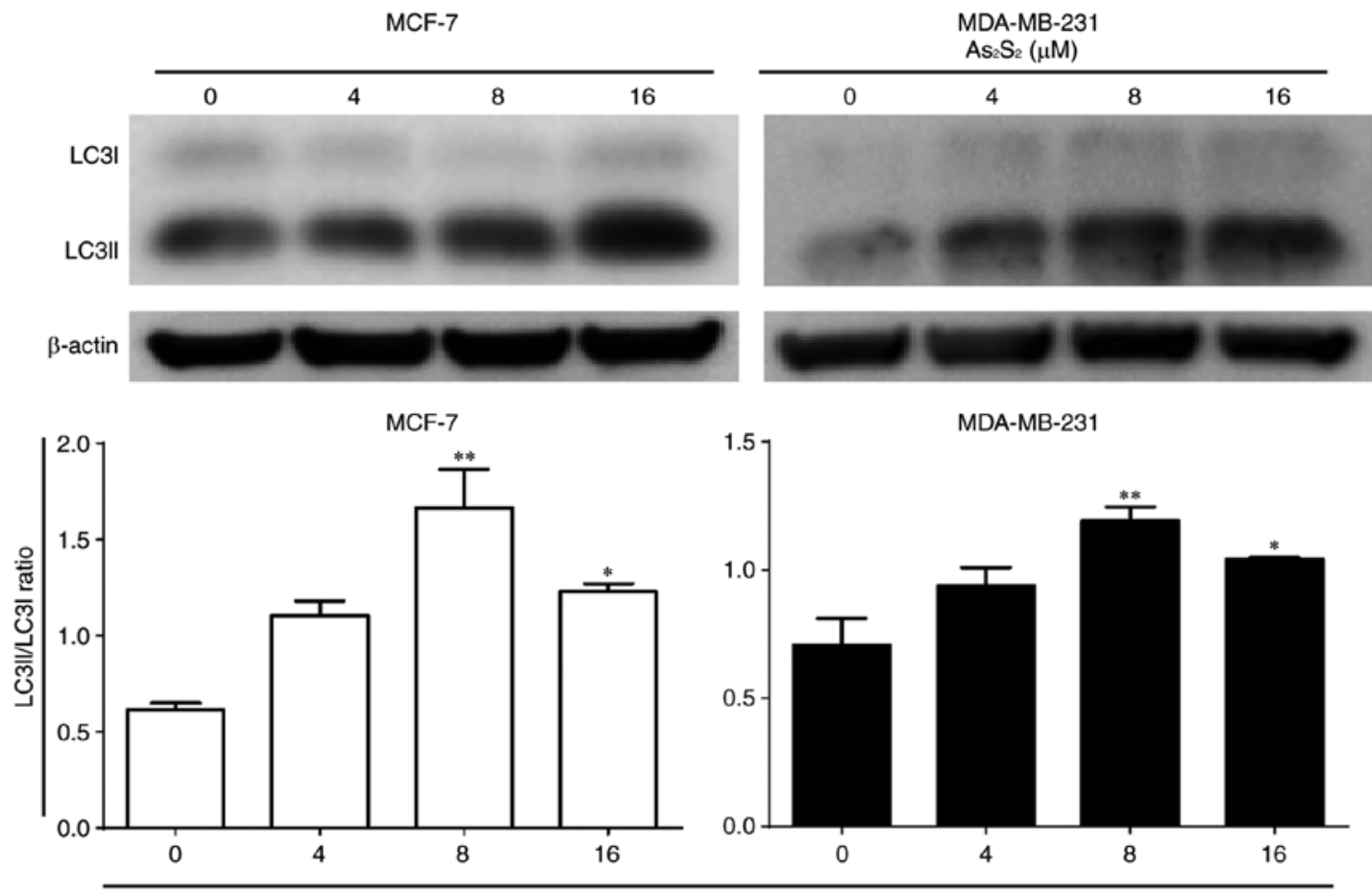

Concentration of $\mathrm{As}_{2} \mathrm{~S}_{2}(\mu \mathrm{M})$

Figure 11. Effects of $\mathrm{As}_{2} \mathrm{~S}_{2}$ on the expression of autophagy hallmarks in breast cancer cells. MCF-7 cells were treated with different concentrations of As $\mathrm{S}_{2}$ $(0,4,8$ and $16 \mu \mathrm{M})$ for $48 \mathrm{~h}$. Western blot assays were performed to examine the effects of $\mathrm{As}_{2} \mathrm{~S}_{2}$ on the expression of the autophagy markers LC3-I and LC3-II in the two cell lines after $48 \mathrm{~h}$ of treatment. The ratio of LC3-II to LC3-I was calculated to determine the autophagic level. $\beta$-actin was used as an internal control. All images are representative of three independent analyses from three independent cellular preparations. ${ }^{*} \mathrm{P}<0.05,{ }^{* *} \mathrm{P}<0.01$ vs. control $\left(0 \mu \mathrm{M} A s_{2} \mathrm{~S}_{2}\right)$. LC3, microtubule-associated protein 1A/1B-light chain 3.
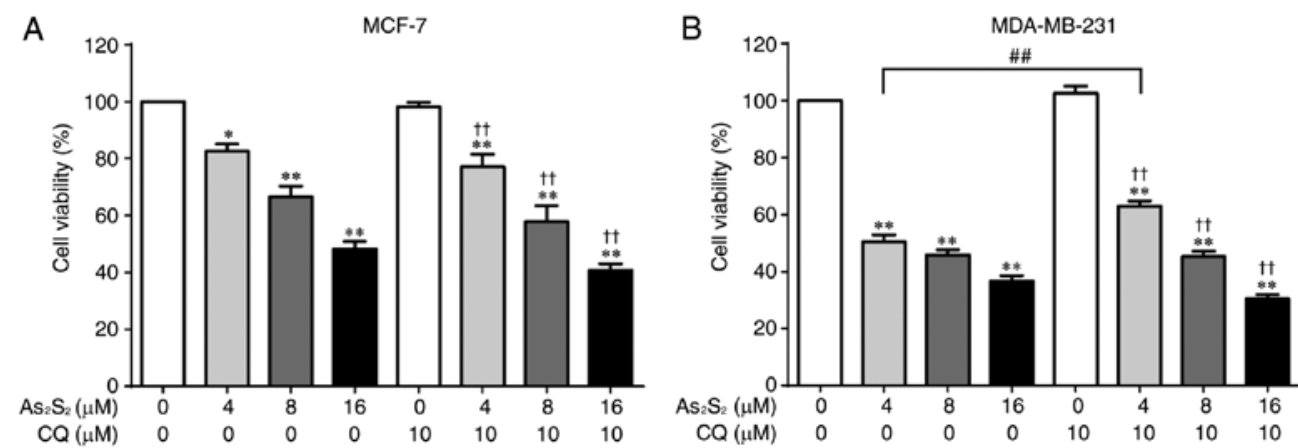

Figure 12. Cell viability in breast cancer cells following autophagy inhibition and $\mathrm{As}_{2} \mathrm{~S}_{2}$ treatment. (A) MCF-7 and (B) MDA-MB-231 cells were pretreated with $10 \mu \mathrm{M} \mathrm{CQ}$ for $1 \mathrm{~h}$ before treatment with various concentrations $(0,4,8$ and $16 \mu \mathrm{M})$ of $\mathrm{As}_{2} \mathrm{~S}_{2}$ for $48 \mathrm{~h}$. Cell viability was determined using Cell Counting Kit-8 assays. Results are presented as the mean \pm standard error of the mean ( $\mathrm{n} \geq 3)$. ${ }^{*} \mathrm{P}<0.05,{ }^{*} \mathrm{P}<0.01$ vs. control $\left(0 \mu \mathrm{M} \mathrm{As} \mathrm{S}_{2} \mathrm{~S}_{2}\right.$ and $\left.0 \mu \mathrm{M} \mathrm{CQ}\right)$; ${ }^{\dagger} \mathrm{P}<0.01$ vs. control $\left(0 \mu \mathrm{M} \mathrm{As}_{2} \mathrm{~S}_{2}\right.$ and $\left.10 \mu \mathrm{M} \mathrm{CQ}\right) ;{ }^{\# \#} \mathrm{P}<0.01$ vs. respective $\mathrm{As}_{2} \mathrm{~S}_{2}$ treatment groups in the absence of $\mathrm{CQ}$. CQ, chloroquine diphosphate.
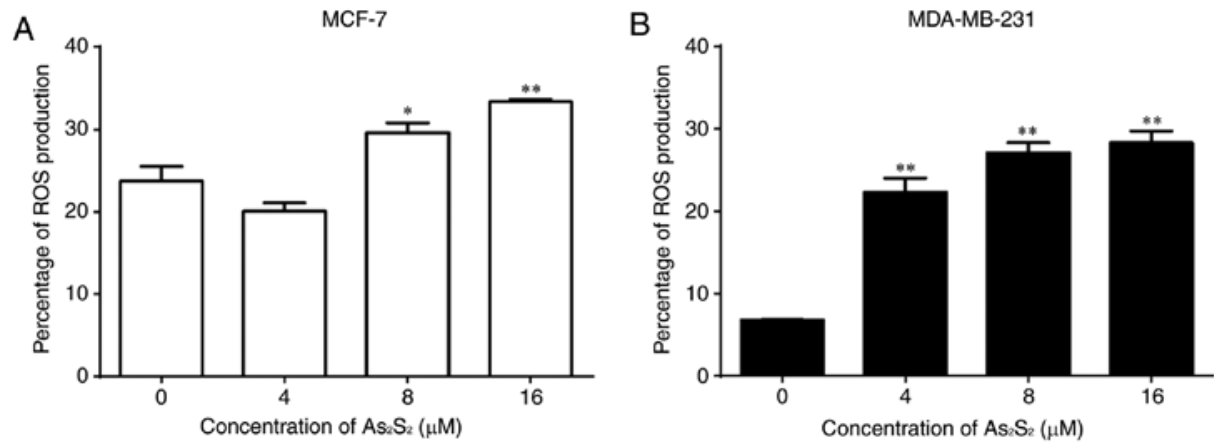

Figure 13. Effects of $\mathrm{As}_{2} \mathrm{~S}_{2}$ on ROS production in breast cancer cells. (A) MCF-7 and (B) MDA-MB-231 cells were treated with different concentrations of $\mathrm{As}_{2} \mathrm{~S}_{2}(0,4,8$ and $16 \mu \mathrm{M})$ for $48 \mathrm{~h}$. Intracellular ROS levels were analyzed using the ROS-responsive dye 2',7'-dichlorofluorescin diacetate followed by a flow cytometric assay. Results are presented as the mean \pm standard error of the mean $(\mathrm{n} \geq 3)$. ${ }^{*} \mathrm{P}<0.05,{ }^{* *} \mathrm{P}<0.01$ vs. control $\left(0 \mu \mathrm{M} \mathrm{As}_{2} \mathrm{~S}_{2}\right)$. 


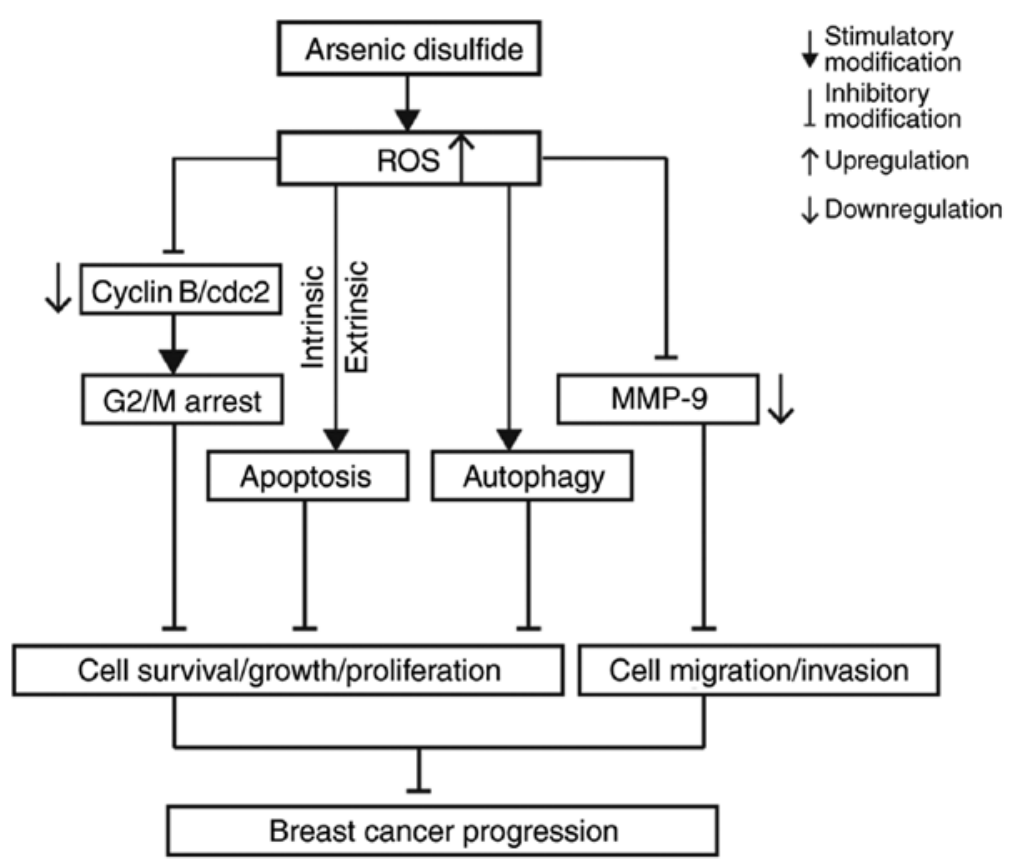

Figure 14. Schematic diagram of the potential molecular mechanisms underlying $\mathrm{As}_{2} \mathrm{~S}_{2}$-hampered carcinoma progression in MCF-7 and MDA-MB-231 cells ROS, reactive oxygen species; MMP-9, matrix metalloproteinase 9; cdc2, cell division cycle 2.

As presented in Fig. 13, $\mathrm{As}_{2} \mathrm{~S}_{2}$ induced the accumulation of ROS in a dose-dependent manner in the two breast cancer cell lines. The proportions of ROS production significantlyincreased from $23.73 \pm 1.78$ in the control to $29.60 \pm 1.20(\mathrm{P}=0.0353)$ and $33.33 \pm 0.32 \%(\mathrm{P}=0.0022)$ by $\mathrm{As}_{2} \mathrm{~S}_{2}$ at 8 and $16 \mu \mathrm{M}$ in MCF-7 cells, respectively. In MDA-MB-231 cells, $\mathrm{As}_{2} \mathrm{~S}_{2}$ significantly increased the proportions of ROS production from $6.80 \pm 0.06 \%$ in the control to $22.30 \pm 1.72(\mathrm{P}=0.0001)$, $27.10 \pm 1.20(\mathrm{P}<0.0001)$ and $28.30 \pm 1.43 \%(\mathrm{P}<0.0001)$ at $\mathrm{As}_{2} \mathrm{~S}_{2}$ concentrations of 4,8 and $16 \mu \mathrm{M}$, respectively.

\section{Discussion}

Previous studies have identified the antitumor effect of $\mathrm{As}_{2} \mathrm{~S}_{2}$ against hematopoietic and solid cancer cell lines $(5-7,20,21)$; however, few have investigated the effects of $\mathrm{As}_{2} \mathrm{~S}_{2}$ against breast cancer cell lines. In the present study, the anticancer effect of $\mathrm{As}_{2} \mathrm{~S}_{2}$ on the proliferation and migration of two distinctive subtypes of breast carcinoma cells (MCF-7 and MDA-MB-231) and the molecular mechanisms underlying these effects were investigated, particularly with regard to the activation of PCD. To the best of our knowledge, the present study is the first focusing on the two classical PCD pathways, i.e. apoptosis and autophagy, induced by $\mathrm{As}_{2} \mathrm{~S}_{2}$ in human breast cancer cell lines.

Tumor metastasis, the most deadly aspect of cancer, is a multistep aggressive process involving cell proliferation and cell migration $(42,43)$. In the present study, the antitumor effects of $\mathrm{As}_{2} \mathrm{~S}_{2}$ against the development of breast cancer cells, including cell proliferation, survival and migration, were investigated. Results obtained from a CCK-8 assay indicated that $\mathrm{As}_{2} \mathrm{~S}_{2}$ significantly inhibited the cell viabilities in the two cell lines in a dose-dependent manner. Consistent with these results, the data visualized and obtained using the calcein-AM staining test showed the potent induction of cell death by $\mathrm{As}_{2} \mathrm{~S}_{2}$ in the two cell lines. In addition, the results from wound healing assays indicated a significant decrease in cell invasion by treatment with $\mathrm{As}_{2} \mathrm{~S}_{2}$ in a dose-dependent manner in the two cell lines, which further suggested the tumor suppressive effects of $\mathrm{As}_{2} \mathrm{~S}_{2}$ by repressing the proliferative and migratory abilities of breast carcinoma cells. MMPs are associated with extracellular matrix degradation, which leads to cancer cell invasion and metastasis. MMP-9 is a key factor that contributes to the metastatic potential and cancer progression (44). The migration and invasion of cancer cells are facilitated by MMP-9. Thus, downregulating MMP-9 may be a possible strategy for attenuating the progression of cancer cells (45). The results of the present study indicated that $\mathrm{As}_{2} \mathrm{~S}_{2}$ decreased the protein expression of MMP-9 in the two breast cancer cell lines in a dose-dependent manner, which may account for the decrease in migration in the two cell lines following $\mathrm{As}_{2} \mathrm{~S}_{2}$ treatment.

Cell cycle dysfunction is a common feature of proliferating and metastatic breast tumor cells (46); targeting cell cycle regulation is therefore an important therapeutic strategy. In the present study, it was demonstrated that $\mathrm{As}_{2} \mathrm{~S}_{2}$ treatment exerted pronounced cell cycle arrest at $\mathrm{G}_{2} / \mathrm{M}$ phase in the two breast cancer cell lines in a dose-dependent manner. In addition, $\mathrm{As}_{2} \mathrm{~S}_{2}$ triggered $\mathrm{G}_{0} / \mathrm{G}_{1}$-phase arrest in MCF-7 cells, but S-phase arrest in MDA-MB-231 cells. The exertion of arrest at different phases between the two cell lines is likely to be due to characteristics specific to these cells as distinct subtypes of breast carcinoma. Considering the observed cell cycle arrest, the results of the present study suggest that $\mathrm{As}_{2} \mathrm{~S}_{2}$ treatment regulates the expression of cell cycle-associated proteins involved in the corresponding phases of the cell cycle in each of the breast cancer cell lines. For example, as the main regulatory proteins in $\mathrm{G}_{2} / \mathrm{M}$ phase $(47,48)$, the expression of cyclin $\mathrm{B} 1$ and $\mathrm{Cdc} 2$ was regulated by $\mathrm{As}_{2} \mathrm{~S}_{2}$ treatment in the two cell lines, which is consistent with the blockage of the cell cycle at $\mathrm{G}_{2} / \mathrm{M}$ by $\mathrm{As}_{2} \mathrm{~S}_{2}$ treatment. Intriguingly, the protein 
expression of cyclin $\mathrm{B} 1$ was regulated by $\mathrm{As}_{2} \mathrm{~S}_{2}$ in an opposite manner between MCF-7 and MDA-MB-231 cells, possibly due to biological variations and distinctions between these two cell lines. In addition to regulating $\mathrm{G}_{2} / \mathrm{M}$ phase, $\mathrm{Cdc} 2$ has also been described as a key regulator associated with $\mathrm{G}_{0} / \mathrm{G}_{1}$ and $\mathrm{S}$ phases $(38,39)$, which accounts for the cell cycle arrest observed at $\mathrm{G}_{0} / \mathrm{G}_{1}$ phase in MCF-7 cells and at the $S$ phase in MDA-MB-231 cells.

Apoptosis and autophagy are two well-known PCD mechanisms that serve essential functions in maintaining organismal and cellular homeostasis (49). Apoptosis, regarded as a major mechanism of chemotherapy-induced cell death (50), is characterized by typical morphological changes, such as nuclear condensation and fragmentation. In the present study, apoptosis was significantly induced by $\mathrm{As}_{2} \mathrm{~S}_{2}$ treatment in the two breast cancer cell lines, as demonstrated using the Annexin V staining assay and visualized using the Hoechst 33342 staining assay. In addition, the induction of apoptosis in the two breast cancer cell lines was further confirmed by the activation of caspase- 8 and -7 , as well as the regulation of proteins in the Bcl-2 family, which resulted in an increase in the $\mathrm{Bax} / \mathrm{Bcl}-2$ ratio along with the decreased expression of Bcl-xl. An essential step in triggering apoptosis is the activation of caspases, a family of cysteine proteases that are ubiquitously expressed as death proteases $(23,51)$. The caspase family has traditionally been divided into initiator and effector caspases. Activated initiator caspases, such as caspase-8, -9 and -10 , subsequently initiate a caspase cascade of downstream effector caspases (52). Effector caspases, such as caspase-3, -6 and -7, are understood to execute apoptosis following being triggered by initiator caspases (52). Two principal signaling pathways exist to induce cell apoptosis: The extrinsic (cell death receptor) pathway and the intrinsic (mitochondrial) pathway (53). Of note, caspase- 8 has been regarded as a core initiating component of the extrinsic pathway, subsequently activating the execution phase of apoptosis (e.g. activating effector caspase-7) (54). Bcl-2 family proteins are categorized into subgroups on the basis of their pro- or anti-apoptotic actions: Pro-apoptotic proteins, such as Bax, and anti-apoptotic proteins, such as Bcl-2 and Bcl-xl. These Bcl-2 family proteins serve an important function in initiating the intrinsic apoptotic pathway $(55,56)$. In the present study, the expression of caspase- 8 and the $\mathrm{Bax} / \mathrm{Bcl}-2$ ratio were significantly increased, whereas the expression of Bcl-xl was markedly decreased following $\mathrm{As}_{2} \mathrm{~S}_{2}$ treatment, suggesting that the extrinsic and intrinsic pathways were involved in $\mathrm{As}_{2} \mathrm{~S}_{2}$-induced apoptosis in the two breast cancer cell lines.

Apoptosis and autophagy normally occur in the same cell, primarily in a mutually interactive manner under the same cellular conditions $(24,49)$. Autophagy, a catabolic process for the degradation of unnecessary and dysfunctional cytosolic components and organelles, has generally been regarded as the type II (non-apoptotic) PCD and is deemed an important mechanism involved in the tumor control process $(57,58)$. LC3 is a key protein involved in initiating autophagy, wherein LC3-I is lipidated and converted into LC3-II. The ratio of LC3-II/LC3-I is widely used as a primary marker of autophagy activation (41). The results of the present study indicated that $\mathrm{As}_{2} \mathrm{~S}_{2}$ treatment induced an increase in the ratio of LC3-II/LC3-I in the two breast cancer cell lines, suggesting that autophagy occurs in breast cancer cells following exposure to $\mathrm{As}_{2} \mathrm{~S}_{2}$. Bcl-2 is an intermediary protein shared by apoptosis and autophagy, serving an anti-apoptotic and anti-autophagy function in the two processes $(29,59)$. The results of the present study indicated that $\mathrm{As}_{2} \mathrm{~S}_{2}$ treatment significantly decreased the protein expression of the anti-apoptotic $\mathrm{Bcl}-2$, which may in turn potentiate the induction of autophagy. Intriguingly, autophagy is commonly regarded as a double-edged sword $(60,61)$ and may positively or negatively influence cancer cell growth (62). To improve understanding of the function of autophagy in the present study, CQ, a pharmacological inhibitor of autophagy, was used to clarify whether or not $\mathrm{As}_{2} \mathrm{~S}_{2}$-induced cell death was associated with the induction of autophagy. The results indicated that CQ significantly reversed the inhibitory effect of $\mathrm{As}_{2} \mathrm{~S}_{2}(4 \mu \mathrm{M})$ on the cell viability in MDA-MB-231 cells, indicating that autophagy induced by $\mathrm{As}_{2} \mathrm{~S}_{2}$ at a relatively low concentration was indeed involved in the death of MDA-MB-231 cells. In contrast, CQ had little effect on the death of MCF-7 and MDA-MB-231 cells in the presence of relatively high concentrations (8 and $16 \mu \mathrm{M})$ of $\mathrm{As}_{2} \mathrm{~S}_{2}$, suggesting that the induction of cell death is primarily through apoptosis and cell cycle arrest, as indicated by the results of the present study, rather than autophagy.

ROS help to regulate a series of biological processes, including PCD (63). It has been identified that the accumulation of ROS is associated with cell apoptosis, cell cycle arrest and autophagy induced by anticancer agents, which consequently leads to negative effects on the cell survival, proliferation and metastasis (44,64-67). In the present study, results from flow cytometric analyses indicated that the ROS level in MCF-7 and MDA-MB-231 cells significantly increased following $\mathrm{As}_{2} \mathrm{~S}_{2}$ treatment in a dose-dependent manner, which may potentiate the induction of apoptosis, cell cycle arrest and autophagy in the two cell lines, triggered by $\mathrm{As}_{2} \mathrm{~S}_{2}$ treatment. Accordingly, the oxidative stress generated by ROS production and the activated PCD pathway markedly inhibited cell viability, decreased the live cell number, suppressed cell viability, attenuated cell migration and consequently decreased cell progression in MCF-7 and MDA-MB-231 cells. The potential molecular mechanisms underlying the inhibitory effect of $\mathrm{As}_{2} \mathrm{~S}_{2}$ on breast carcinoma progression are presented in Fig. 14.

In conclusion, the results of the present study identified the antitumor effects of $\mathrm{As}_{2} \mathrm{~S}_{2}$ against breast carcinoma in vitro as inhibition of cell viability, decreased cell survival and attenuated invasion of MCF-7 and MDA-MB-231 cells. These effects were associated with inhibition of cell cycle progression, the induction of apoptosis and autophagy, a decrease in MMP-9 expression and an increase in ROS accumulation. In future studies, we intend to investigate the therapeutic potential of $\mathrm{As}_{2} \mathrm{~S}_{2}$ in vivo in the treatment of breast cancer in animal models.

\section{Acknowledgements}

Not applicable.

\section{Funding}

The present study was supported in part by the China Scholarship Council (grant no. 201709110064). 


\section{Availability of data and materials}

The analyzed datasets generated during the study are available from the corresponding author on reasonable request, while preserving the necessary confidentiality and anonymity.

\section{Authors' contributions}

TH conceived and designed the study and critically revised the manuscript. YZ designed and performed the experiments, analyzed the data and was a major contributor in writing the manuscript. KO, KS, BY, ST and NT gave advice on the experiments and contributed with reagents and technical assistance. TH and NT supervised the study. All authors have read and approved the final manuscript.

\section{Ethics approval and consent to participate}

Not applicable.

\section{Patient consent for publication}

Not applicable.

\section{Competing interests}

The authors declare that they have no competing interests.

\section{References}

1. Wang H, Liu Z, Gou Y, Qin Y, Xu Y, Liu J and Wu JZ: Apoptosis and necrosis induced by novel realgar quantum dots in human endometrial cancer cells via endoplasmic reticulum stress signaling pathway. Int J Nanomedicine 10: 5505-5512, 2015.

2. Wang L, Zhou GB, Liu P, Song JH, Liang Y, Yan XJ, Xu F, Wang BS, Mao JH, Shen ZX, et al: Dissection of mechanisms of Chinese medicinal formula Realgar-Indigo naturalis as an effective treatment for promyelocytic leukemia. Proc Natl Acad Sci USA 105: 4826-4831, 2008.

3. Zhang QY, Mao JH, Liu P, Huang QH, Lu J, Xie YY, Weng L, Zhang Y, Chen Q, Chen SJ, et al: A systems biology understanding of the synergistic effects of arsenic sulfide and Imatinib in BCR/ABL-associated leukemia. Proc Natl Acad Sci USA 106 3378-3383, 2009.

4. Liu Y, He P, Cheng X and Zhang M: Long-term outcome of 31 cases of refractory acute promyelocytic leukemia treated with compound realgar natural indigo tablets administered alternately with chemotherapy. Oncol Lett 10: 1184-1190, 2015.

5. Zhang L, Kim S, Ding W, Tong Y, Zhang X, Pan M and Chen S: Arsenic sulfide inhibits cell migration and invasion of gastric cancer in vitro and in vivo. Drug Des Devel Ther 9: 5579-5590, 2015.

6. Wang G, Zhang T, Sun W, Wang H, Yin F, Wang Z, Zuo D, Sun M, Zhou Z, Lin B, et al: Arsenic sulfide induces apoptosis and autophagy through the activation of ROS/JNK and suppression of Akt/mTOR signaling pathways in osteosarcoma. Free Radic Biol Med 106: 24-37, 2017.

7. Song P, Chen P, Wang D, Wu Z, Gao Q, Wang A, Zhu R, Wang Y, Wang X, Zhao L, et al: Realgar transforming solution displays anticancer potential against human hepatocellular carcinoma HepG2 cells by inducing ROS. Int J Oncol 50: 660-670, 2017.

8. Qin YU, Wang H, Liu ZY, Liu J and Wu JZ: Realgar quantum dots induce apoptosis and necrosis in HepG2 cells through endoplasmic reticulum stress. Biomed Rep 3: 657-662, 2015.

9. Wu JZ and Ho PC: Evaluation of the in vitro activity and in vivo bioavailability of realgar nanoparticles prepared by cryo-grinding. Eur J Pharm Sci 29: 35-44, 2006.

10. Ding W, Zhang L, Kim S, Tian W, Tong Y, Liu J, Ma Y and Chen S: Arsenic sulfide as a potential anti-cancer drug. Mol Med Rep 11: 968-974, 2015.
11. Tse WP, Cheng CH, Che CT and Lin ZX: Arsenic trioxide, arsenic pentoxide, and arsenic iodide inhibit human keratinocyte proliferation through the induction of apoptosis. J Pharmacol Exp Ther 326: 388-394, 2008.

12. Zhao Y, Onda K, Yuan B, Tanaka S, Kiyomi A, Sugiyama K, Sugiura M, Takagi N and Hirano T: Arsenic disulfide-induced apoptosis and its potential mechanism in two- and three-dimensionally cultured human breast cancer MCF-7 cells. Int J Oncol 52: 1959-1971, 2018.

13. Zhao Y, Yuan B, Onda K, Sugiyama K, Tanaka S, Takagi N and Hirano T: Anticancer efficacies of arsenic disulfide through apoptosis induction, cell cycle arrest, and pro-survival signal inhibition in human breast cancer cells. Am J Cancer Res 8: 366-386, 2018

14. Uematsu N, Zhao Y, Kiyomi A, Yuan BO, Onda K, Tanaka S, Sugiyama K, Sugiura M, Takagi N, Hayakawa A and Hirano T: Chemo-sensitivity of two-dimensional monolayer and three-dimensional spheroid of breast cancer MCF-7 cells to daunorubicin, docetaxel, and arsenic disulfide. Anticancer Res 38: 2101-2108, 2018.

15. Kamangar F, Dores GM and Anderson WF: Patterns of cancer incidence, mortality, and prevalence across five continents: Defining priorities to reduce cancer disparities in different geographic regions of the world. J Clin Oncol 24: 2137-2150, 2006.

16. Michailidou K, Hall P, Gonzalez-Neira A, Ghoussaini M, Dennis J, Milne RL, Schmidt MK, Chang-Claude J, Bojesen SE, Bolla MK, et al: Large-scale genotyping identifies 41 new loci associated with breast cancer risk. Nat Genet 45: 353-361, 361e1-2, 2013.

17. Recht A, Come SE, Henderson IC, Gelman RS, Silver B, Hayes DF, Shulman LN and Harris JR: The sequencing of chemotherapy and radiation therapy after conservative surgery for early-stage breast cancer. N Engl J Med 334: 1356-1361, 1996.

18. Cicconi L and Lo-Coco F: Current management of newly diagnosed acute promyelocytic leukemia. Ann Oncol 27: 1474-1481, 2016.

19. Chow SK, Chan JY and Fung KP: Suppression of cell proliferation and regulation of estrogen receptor alpha signaling pathway by arsenic trioxide on human breast cancer MCF-7 cells. J Endocrinol 182: 325-337, 2004.

20. Wang X, Zhang X, Xu Z, Wang Z, Yue X and Li H: Reversal effect of arsenic sensitivity in human leukemia cell line K562 and K562/ADM using realgar transforming solution. Biol Pharm Bull 36: 641-648, 2013.

21. Xie QJ, Cao XL, Bai L, Wu ZR, Ma YP and Li HY: Anti-tumor effects and apoptosis induction by Realgar bioleaching solution in Sarcoma-180 cells in vitro and transplanted tumors in mice in vivo. Asian Pac J Cancer Prev 15: 2883-2888, 2014.

22. Engelberg-Kulka H, Amitai S, Kolodkin-Gal I and Hazan R: Bacterial programmed cell death and multicellular behavior in bacteria. PLoS Genet 2: e135, 2006.

23. Fuchs Y and Steller H: Programmed cell death in animal development and disease. Cell 147: 742-758, 2011.

24. Maiuri MC, Zalckvar E, Kimchi A and Kroemer G: Self-eating and self-killing: Crosstalk between autophagy and apoptosis. Nat Rev Mol Cell Biol 8: 741-752, 2007.

25. Booth LA, Tavallai S, Hamed HA, Cruickshanks N and Dent P. The role of cell signalling in the crosstalk between autophagy and apoptosis. Cell Signal 26: 549-555, 2014.

26. Zimmermann KC, Bonzon C and Green DR: The machinery of programmed cell death. Pharmacol Ther 92: 57-70, 2001.

27. Levine B and Deretic V: Unveiling the roles of autophagy in innate and adaptive immunity. Nat Rev Immunol 7: 767-777, 2007.

28. Eisenberg-Lerner A, Bialik S, Simon HU and Kimchi A: Life and death partners: Apoptosis, autophagy and the cross-talk between them. Cell Death Differ 16: 966-975, 2009.

29. Zambrano J and Yeh ES: Autophagy and apoptotic crosstalk: Mechanism of therapeutic resistance in HER2-positive breast cancer. Breast Cancer 10: 13-23, 2016.

30. Shi D, Liu Y, Xi R, Zou W, Wu L, Zhang Z, Liu Z, Qu C, Xu B and Wang $X$ : Caveolin-1 contributes to realgar nanoparticle therapy in human chronic myelogenous leukemia K562 cells. Int J Nanomedicine 11: 5823-5835, 2016.

31. Pastorek M, Gronesova P, Cholujova D, Hunakova L, Bujnakova Z, Balaz P, Duraj J, Lee TC and Sedlak J: Realgar (As4S4) nanoparticles and arsenic trioxide (As2O3) induced autophagy and apoptosis in human melanoma cells in vitro. Neoplasma 61: 700-709, 2014. 
32. Shi X, Zhang Y, Zheng J and Pan J: Reactive oxygen species in cancer stem cells. Antioxid Redox Signal 16: 1215-1228, 2012.

33. Gupta SC, Hevia D, Patchva S, Park B, Koh W and Aggarwal BB: Upsides and downsides of reactive oxygen species for cancer: The roles of reactive oxygen species in tumorigenesis, prevention, and therapy. Antioxid Redox Signal 16: 1295-1322, 2012.

34. Trachootham D, Alexandre J and Huang P: Targeting cancer cells by ROS-mediated mechanisms: A radical therapeutic approach? Nat Rev Drug Discov 8: 579-591, 2009.

35. Jing Y, Dai J, Chalmers-Redman RM, Tatton WG and Waxman S: Arsenic trioxide selectively induces acute promyelocytic leukemia cell apoptosis via a hydrogen peroxide-dependent pathway. Blood 94: 2102-2111, 1999.

36. Chen YC, Lin-Shiau SY and Lin JK: Involvement of reactive oxygen species and caspase 3 activation in arsenite-induced apoptosis. J Cell Physiol 177: 324-333, 1998.

37. Maeda H, Hori S, Nishitoh H, Ichijo H, Ogawa O, Kakehi Y and Kakizuka A: Tumor growth inhibition by arsenic trioxide $\left(\mathrm{As}_{2} \mathrm{O}_{3}\right)$ in the orthotopic metastasis model of androgen-independent prostate cancer. Cancer Res 61: 5432-5440, 2001.

38. Jayakumar AR, Bak LK, Rama Rao KV, Waagepetersen HS Schousboe A and Norenberg MD: Neuronal cell death induced by mechanical percussion trauma in cultured neurons is not preceded by alterations in glucose, lactate and glutamine metabolism. Neurochem Res 41: 307-315, 2016.

39. Ouyang L, Shi Z, Zhao S, Wang FT, Zhou TT, Liu B and Bao JK: Programmed cell death pathways in cancer: A review of apoptosis, autophagy and programmed necrosis. Cell Prolif 45 487-498, 2012.

40. Li Y, Chang Y, Ye N, Dai D, Chen Y, Zhang N, Sun G and Sun Y: Advanced glycation end products inhibit the proliferation of human umbilical vein endothelial cells by inhibiting cathepsin D. Int J Mol Sci 18: E436, 2017.

41. Aparicio IM, Martin Muñoz P, Salido GM, Peña FJ and Tapia JA: The autophagy-related protein LC3 is processed in stallion spermatozoa during short- and long-term storage and the related stressful conditions. Animal 10: 1182-1191, 2016.

42. Singh BN, Singh HB, Singh A, Naqvi AH and Singh BR: Dietary phytochemicals alter epigenetic events and signaling pathways for inhibition of metastasis cascade: Phytoblockers of metastasis cascade. Cancer Metastasis Rev 33: 41-85, 2014.

43. Zhou J, Zhu YF, Chen XY, Han B, Li F, Chen JY, Peng XL, Luo LP, Chen W and Yu XP: Black rice-derived anthocyanins inhibit HER-2-positive breast cancer epithelial-mesenchymal transition-mediated metastasis in vitro by suppressing FAK signaling. Int J Mol Med 40: 1649-1656, 2017.

44. Si L, Yan X, Hao W, Ma X, Ren H, Ren B, Li D, Dong Z and Zheng Q: Licochalcone D induces apoptosis and inhibits migration and invasion in human melanoma A375 cells. Oncol Rep 39: 2160-2170, 2018

45. Jacob A and Prekeris R: The regulation of MMP targeting to invadopodia during cancer metastasis. Front Cell Dev Biol 3: 4, 2015.

46. Diaz-Moralli S, Tarrado-Castellarnau M, Miranda A and Cascante M: Targeting cell cycle regulation in cancer therapy. Pharmacol Ther 138: 255-271,2013.

47. Stewart ZA, Westfall MD and Pietenpol JA: Cell-cycle dysregulation and anticancer therapy. Trends Pharmacol Sci 24: 139-145, 2003.

48. Marconett CN, Morgenstern TJ, San Roman AK, Sundar SN, Singhal AK and Firestone GL: BZL101, a phytochemical extract from the Scutellaria barbata plant, disrupts proliferation of human breast and prostate cancer cells through distinct mechanisms dependent on the cancer cell phenotype. Cancer Biol Ther 10: 397-405, 2010.

49. Mariño G, Niso-Santano M, Baehrecke EH and Kroemer G: Self-consumption: The interplay of autophagy and apoptosis. Nat Rev Mol Cell Biol 15: 81-94, 2014.

50. Ricci MS and Zong WX: Chemotherapeutic approaches for targeting cell death pathways. Oncologist 11: 342-357, 2006.

51. Earnshaw WC, Martins LM and Kaufmann SH: Mammalian caspases: Structure, activation, substrates, and functions during apoptosis. Annu Rev Biochem 68: 383-424, 1999.
52. Kadam CY and Abhang SA: Apoptosis markers in breast cancer therapy. Adv Clin Chem 74: 143-193, 2016.

53. Suen DF, Norris KL and Youle RJ: Mitochondrial dynamics and apoptosis. Genes Dev 22: 1577-1590, 2008.

54. Dickens LS, Boyd RS, Jukes-Jones R, Hughes MA, Robinson GL, Fairall L, Schwabe JW, Cain K and Macfarlane M: A death effector domain chain DISC model reveals a crucial role for caspase-8 chain assembly in mediating apoptotic cell death. Mol Cell 47: 291-305, 2012

55. Martinou JC and Youle RJ: Mitochondria in apoptosis: Bcl-2 family members and mitochondrial dynamics. Dev Cell 21: 92-101, 2011.

56. Pettersson F, Dalgleish AG, Bissonnette RP and Colston KW: Retinoids cause apoptosis in pancreatic cancer cells via activation of RAR-gamma and altered expression of $\mathrm{Bcl}-2 / \mathrm{Bax} . \mathrm{Br}$ J Cancer 87: 555-561, 2002

57. Liu F, Gao S, Yang Y, Zhao X, Fan Y, Ma W, Yang D, Yang A and Yu Y: Curcumin induced autophagy anticancer effects on human lung adenocarcinoma cell line A549. Oncol Lett 14: 2775-2782, 2017.

58. Kim KY, Park KI, Kim SH, Yu SN, Park SG, Kim YW, Seo YK, Ma JY and Ahn SC: Inhibition of autophagy promotes salinomycin-induced apoptosis via reactive oxygen species-mediated $\mathrm{PI} 3 \mathrm{~K} / \mathrm{AKT} / \mathrm{mTOR}$ and ERK/p38 MAPK-dependent signaling in human prostate cancer cells. Int J Mol Sci 18: E1088, 2017.

59. Tang F, Wang B, Li N, Wu Y, Jia J, Suo T, Chen Q, Liu YJ and Tang J: RNF185, a novel mitochondrial ubiquitin E3 ligase, regulates autophagy through interaction with BNIP1. PLoS One 6: e24367, 2011

60. Li Y, Cui Y, Wang W, Ma M, Li M and Chen S: Effect of the serum inhibited gene (Si1) on autophagy and apoptosis in MCF-7 breast cancer cells. Cell Physiol Biochem 41: 2268-2278, 2017.

61. Zeng Y, Li S, Wu J, Chen W, Sun H, Peng W, Yu X and Yang X: Autophagy inhibitors promoted aristolochic acid I induced renal tubular epithelial cell apoptosis via mitochondrial pathway but alleviated nonapoptotic cell death in mouse acute aritolochic acid nephropathy model. Apoptosis 19: 1215-1224, 2014.

62. Subramani R, Gonzalez E, Arumugam A, Nandy S, Gonzalez V, Medel J, Camacho F, Ortega A, Bonkoungou S, Narayan M, et al: Nimbolide inhibits pancreatic cancer growth and metastasis through ROS-mediated apoptosis and inhibition of epithelial-to-mesenchymal transition. Sci Rep 6: 19819, 2016.

63. Wang L, Li P, Hu W, Xia Y, Hu C, Liu L and Jiang X: CD $44^{+}$CD $24^{+}$ subset of PANC-1 cells exhibits radiation resistance via decreased levels of reactive oxygen species. Oncol Lett 14: 1341-1346, 2017.

64. Banerjee A, Banerjee V, Czinn S and Blanchard T: Increased reactive oxygen species levels cause ER stress and cytotoxicity in andrographolide treated colon cancer cells. Oncotarget 8: 26142-26153, 2017.

65. Li B, Zhao S, Geng R, Huo Z and Zhang H: The sineoculis homeobox Homolog 1 (SIX1) gene regulates paclitaxel resistance by affecting reactive oxygen species and autophagy in human hepatocellular carcinoma cell line HepG2. Med Sci Monit 24: 2271-2279, 2018

66. Apel K and Hirt H: Reactive oxygen species: Metabolism, oxidative stress, and signal transduction. Annu Rev Plant Biol 55: 373-399, 2004

67. Li L, Cao W, Zheng W, Fan C and Chen T: Ruthenium complexes containing 2,6-bis(benzimidazolyl)pyridine derivatives induce cancer cell apoptosis by triggering DNA damage-mediated p53 phosphorylation. Dalton Trans 41: 12766-12772, 2012.

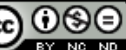

This work is licensed under a Creative Commons Attribution-NonCommercial-NoDerivatives 4.0 International (CC BY-NC-ND 4.0) License. 